\title{
Hedgehogs and Hedgehog-Head Boats in Ancient Egyptian Religion in the Late 3rd Millennium BCE
}

\author{
Julia Clare Francis Hamilton (1)
}

check for updates

Citation: Hamilton, Julia Clare Francis. 2022. Hedgehogs and Hedgehog-Head Boats in Ancient Egyptian Religion in the Late 3rd Millennium BCE. Arts 11: 31. https://doi.org/10.3390/arts11010031

Academic Editors: Branko F. van Oppen de Ruiter and Chiara Cavallo

Received: 21 November 2021

Accepted: 13 January 2022

Published: 8 February 2022

Publisher's Note: MDPI stays neutral with regard to jurisdictional claims in published maps and institutional affiliations.

Copyright: (C) 2022 by the author. Licensee MDPI, Basel, Switzerland. This article is an open access article distributed under the terms and conditions of the Creative Commons Attribution (CC BY) license (https:// creativecommons.org/licenses/by/ $4.0 /)$.
Nederlands Instituut voor het Nabije Oosten (NINO), Leiden University, 2311 BG Leiden, The Netherlands; j.c.f.hamilton@hum.leidenuniv.nl

\begin{abstract}
Hedgehogs held a special place in ancient Egyptian life like many other desert- and marshdwelling animals. Their natural defensive qualities were admired by ancient Egyptians and their bodily parts, notably their hardened spines, were used as ingredients in medico-magical prescriptions. In tomb reliefs of the late 3rd Millennium BCE, hedgehogs are represented being carried alive by offering bearers or as background participants in desert hunting scenes. In later periods of Egyptian history, rattles, small unguent vessels, and scaraboid amulets were made in their shape, all of which are presumed to have had apotropaic purposes. A particular votive object of the Old Kingdom (c. 2686-2181 BCE) is a palm-sized modelled boat with a prow in the shape of a hedgehog head, which has been discovered at sites throughout Egypt. A similar representation of this motif is the so-called 'Henet'-boat (from the word $h n t[j]$ ) with a hedgehog head at the prow facing inwards, which is found in late Old Kingdom art. This article reassesses the role of hedgehogs as protective or apotropaic entities and their association with boats, considering how ancient Egyptians understood their ecology and their predation of snakes, scorpions, and similar stinging creatures. An updated list is provided of known representations of hedgehog-head boats, including petroglyphs and as yet unpublished examples from tombs at Giza and Saqqara. The meaning of the ancient Egyptian word $h n t(j)$ is also rexamined in relation to the representation of riverine and marsh-water boats in Old Kingdom tombs.
\end{abstract}

Keywords: hedgehog; Igel; hérisson; hedgehog-head boat; Igelkopfbug; Old Kingdom; Egypt; votive object

\section{Introduction}

The most comprehensive study of hedgehogs in ancient Egypt to date is by Droste zu Hülshoff (1980), and all major studies of ancient Egyptian fauna include summaries of representations of hedgehogs in ancient Egyptian art and material culture (e.g., Osborn and Osbornová 1998, pp. 19-23; Vernus and Yoyotte 2005, pp. 145-46; Old Kingdom: Evans 2010a, pp. 124-25, 162). This corpus is heavily weighted to evidence from later periods of Egyptian history, from which a greater variety of hedgehog-related objects have survived. Droste zu Hülshoff (1980, p. 45) sought to establish formal and aesthetic criteria for studying hedgehogs in ancient Egyptian art, in order to stimulate further research and interpretive approaches. The present article focuses on a small subgroup of the extant corpus-namely, boats with a hedgehog-head prow occurring among votive objects (Section 4.1) and in funerary art (Section 4.2) - and considers their meaning specific to the late 3rd Millennium BCE, as these representational forms are not known to be attested later in Egyptian history. This article builds upon remarks concerning boats with a hedgehoghead prow (Igelkopfbug) by e.g., Altenmüller (2000, 2005, 2007), Bárta (2001, pp. 140-41), and Tavares and Malak (in Tavares et al. 2014, pp. 554-55; earlier: Tavares 2014) concerning an example of a fragmentary model hedgehog-head boat found at Giza in 2014. I contribute new data to the survey of hedgehog-head boats in Old Kingdom tombs (Tables 1 and 2), including a small number from unpublished tombs at Giza recorded in the Digital Giza Archives and at Saqqara courtesy of personal communication with Yvonne Harpur. I also 
include possible examples in rock inscriptions (petroglyphs) (Table 3). In Section 5, I discuss the orthography of the ancient Egyptian words for hedgehog and hedgehog-head boats in close association with their pictorial representation in Old Kingdom tombs. In Section 6, I propose further links between the ecology and natural behaviours of hedgehogs and their representation in Old Kingdom art as protective creatures.

\section{Hedgehogs in Ancient Egypt}

Hedgehogs have existed alongside ancient Egyptian people since the very earliest periods of sedentary settlement. Hedgehog bones have been found among human refuse at the earliest Neolithic sites of Merimde Beni-Salame in the Western Delta region (Wendorf and Schild 2001, p. 667), as well as Nabta Playa and Bir Kiseiba in Southern Egypt (Brass 2018, tab. 5). Two genera of hedgehogs are found in Egypt today, Hermiechinus and Paraechinus, within which five species of hedgehogs are known: one so-called 'long-eared hedgehog' and several species of desert hedgehog (Osborn and Ibrahim 1980, pp. 57-71; summary: Hoath 2009, pp. 25-29). Differentiating between Hermiechinus and Paraechinus is not yet possible in the extant ancient evidence, and ancient Egyptians may not have done so; however, Evans (2010a, p. 124, n. 124) notes that long-eared hedgehogs are more common in the modern Egyptian landscape, usually being found in 'densely vegetated areas around human settlement ... while desert hedgehogs prefer drier habitats'. Hedgehogs are not known to have played a major part in the ancient Egyptian diet (Ikram 1995, p. 22; cf. Fitzenreiter 2009, p. 320).

The earliest unambiguous artistic representation of a hedgehog occurs in the chapel of Metjen from Saqqara (now Berlin ÄM 1105 in LD II, pl. 3), dated to the ancient Egyptian 4th Dynasty (c. 2613-2494 BCE), in which it appears among a group of registers containing desert animals before Metjen as a hunter (Fitzenreiter 2009, pp. 322-23). Earlier examples from the 4th Millennium BCE may include decorated ceramic vessels from the Naqada I-II periods (c. 3900-3200 BCE), some of which have been identified as hedgehogs on all fours (e.g., Fitzwilliam Museum E.GA.4330.1943 in Vassilika 1995, pp. 10-11), or which carry representations of small, spiky creatures (e.g., white cross-lined vessel from $\mathrm{Hu} / \mathrm{Abadiya}$, Ashmolean Museum E.2778 in Petrie 1901, pl. 14 [93b]; cf. Graff 2009, p. 52 [NI31], p. 77). ${ }^{1}$ In tombs from the late 3rd Millennium BCE (ancient Egyptian 4th-6th Dynasties), hedgehogs are depicted being carried alive in cages by offering bearers as they process towards the tomb owner, as in the tomb of an official named Mereruka at Saqqara (Figure 1a). However, they do not appear in extant scenes of offering piles or in tabular registers of offerings in Old Kingdom tombs, ${ }^{2}$ the significance of which will be discussed in Section 6.

Hedgehogs are commonly depicted in wild habitats, usually as a component of the landscape in desert hunting scenes amidst larger animals in full flight or emerging from their burrow (Figure 1b; overview: Evans 2010a, pp. 124-25; on their burrows: Evans 2011, pp. 109-11). In an exceptional scene from the 5th Dynasty tomb of Pehenuka at Saqqara (D 70), a hedgehog is shown on its back while a panther attacks it (Harpur 1987, p. 530, fig. 188; cf. a similar motif at Beni Hassan: Kanawati and Evans 2014, pl. 36b). Hedgehogs are usually shown alone, but occasionally they also occur in pairs, as in a small number of mating scenes (Evans 2010a, p. 162). Probably for aesthetic reasons, so that they can be seen by the viewer, hedgehogs are often represented well out of proportion to the size of other animals within desert hunting scenes. ${ }^{3}$

It is clear that ancient Egyptian artists distinguished between various types of spiny creatures such as hedgehogs and porcupines (Lippert 2012, pp. 788-89). A comparable representation of a porcupine comes from a relief block from the tomb of Pehenuka at Saqqara (now Berlin ÄM 1132 in Wildung 2011, pp. 38-39), in which the key details differentiating this creature from a hedgehog include the overall length of its quills, which are significantly longer, the presence of a crest of quills at its head and a tail of quills (typical of the North African crested porcupine, Hystrix cristata), and the rounded features of its face and snout (summary: Hoath 2009, pp. 212-13). 


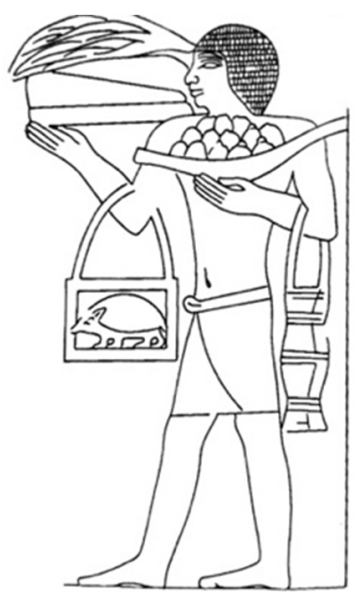

(a)

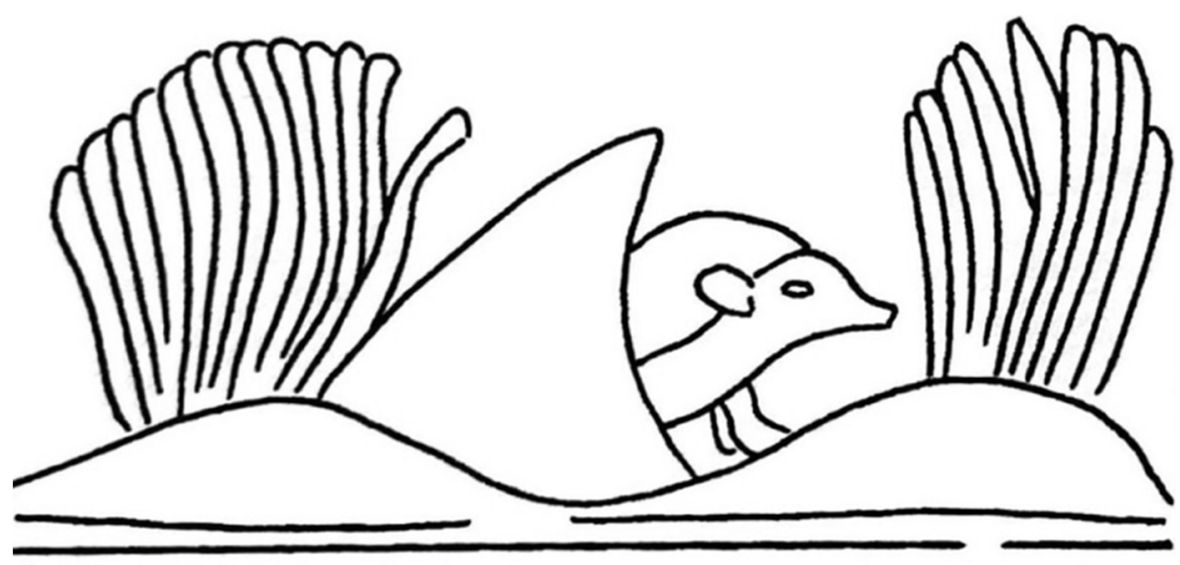

(b)

Figure 1. (a) Detail of offering bearer carrying piled offerings, with a live hedgehog in a cage held in his right arm. East thickness (bottom register) in doorway A3-A4 of Mereruka's chapel, Saqqara. Adapted from line-drawing in Kanawati et al. (2010, pl. 75c). (b) Detail of hedgehog emerging from a burrow in a desert hunting scene. West wall of A3 in Mereruka's chapel, Saqqara. Adapted from line drawing in Kanawati et al. (2010, pl. 73b).

Compared to the Old Kingdom, the corpus of sculptural representations of hedgehogs from the Middle Kingdom onwards contains only a few examples in which a hedgehog is depicted in its defensive position (Droste zu Hülshoff 1980, p. 29). For example, a small number of hedgehog 'rattles' in this form are known, dating to the ancient Egyptian 12th Dynasty (e.g., Brooklyn Museum 59.186), which are presumed to have been shaken in a ritualistic manner (Quirke 2015, p. 126f.). Scaraboid hedgehog amulets (Figure 2a; overview: Andrews 1994, p. 64; Droste zu Hülshoff 1980, pp. 37-44) and statuettes (Figure 2b; Droste zu Hülshoff 1980, pp. 28-32) are also well attested from this period onwards. Like the rattles, they are hypothesised to have had an apotropaic purpose. Small unguent vessels representing a hedgehog on all fours were especially popular in the 1st Millennium BCE, from the Late Period through the Greco-Roman Period (e.g., De Dominicis 2019; Aufrère and Erroux-Morfin 2001; Germond 2014-2015; Droste zu Hülshoff 1980, pp. 33-36).

Hedgehogs were also a source of ingredients in medical prescriptions, some with ritual elements ('magic'), although none of the papyri which record these remedies are known to date earlier than the Second Intermediate Period (c. 1650-1550 BCE). For example, in P. Ebers, dated c. 1534 BCE, a remedy to promote re-growth of hair lost due to the ' $n s s q$ disease' (Wb. II, 336 [14]; Popko et al. 2021, p. 287; possibly alopecia areata), prescribes burning the 'hair' (šnj) of a hedgehog in oil or fat and anointing the head with the mixture for four days (1. 66.7-67.7; Ghalioungui 1987, p. 130, no. 466; Popko et al. 2021, pp. 166-67). From the same papyrus, a later prescription to eliminate the same disease is noted by Paul Ghalioungui (1987, p. 130) to employ 'sympathetic magic': instructions are given to dip a single hedgehog spine (srt) in oil or fat and burn it (1. 91.2-93.5; Ghalioungui 1987, p. 197 no. 771; Popko et al. 2021, pp. 218-19). Although it is never explicitly stated, it seems plausible that these remedies sought to transmit the strength of a hedgehog's spines to the hair of the afflicted areas. ${ }^{4}$ 


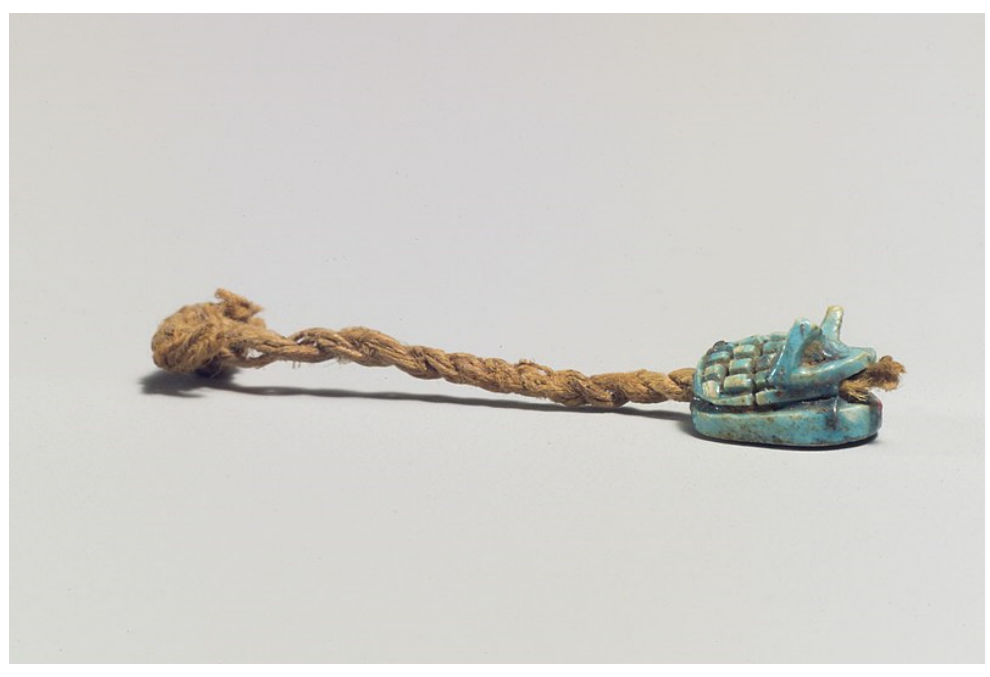

(a)

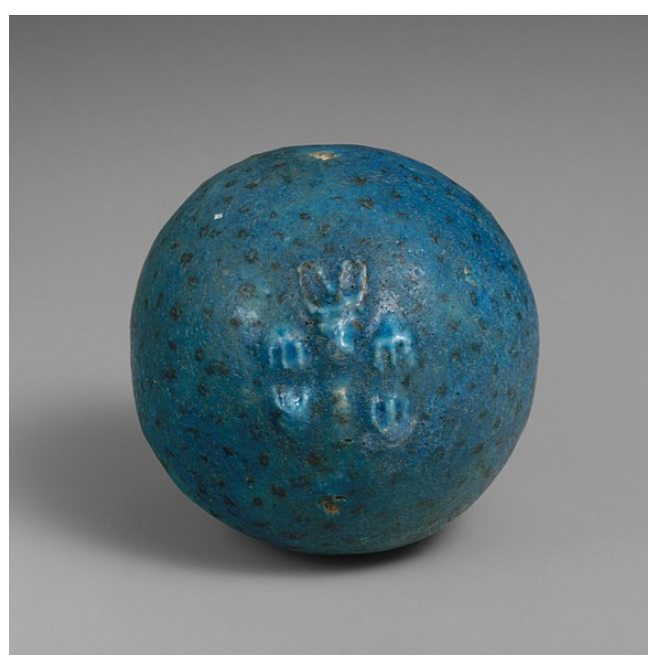

(b)

Figure 2. (a) Glazed steatite hedgehog amulet on string, mid-13th Dynasty Memphis (Lisht North cemetery, pit 995). Metropolitan Museum of Art, New York (22.1.301). Image in Public Domain. (b) Faience spherical modelled hedgehog, 18th Dynasty (location not recorded). Metropolitan Museum of Art, New York (1989.281.91). Image in Public Domain.

The natural and divine world were intrinsically linked in ancient Egyptian thought. The most potent display of this belief came in the form of zoomorphic representations of ancient Egyptian deities. Gods and goddesses could adopt different animal manifestations, such as Thoth who could manifest as an ibis or as a baboon, or Re, who could manifest as a falcon or as a cat (e.g., Fernández Pichel 2017; Roth 2011). Despite the hedgehog occurring across diverse magico-religious settings, they have never been found mummified, ${ }^{5}$ and the only established association between this animal and a goddess named 'Abaset (' $b$ 'st: LGG II, 88 [1-2]) dates to the ancient Egyptian 26th Dynasty (c. 664-525 BCE). ${ }^{6}$ 'Abaset is attested at the Bahariya Oasis in Egypt's Western Desert: in the tomb of Banentiu (Sherbiny and Bassir 2014; Droste zu Hülshoff 1980, pp. 93-94; Fakhry 1942, pp. 65-93), and in another tomb at Fama, near the village of el-Harra, whose owners are unknown (Shaikh Al Arab 2019). Both her origin and how she came to be associated with hedgehogs are obscure. It is possible that an association with a goddess of a desert oasis reflected ancient admiration for how hedgehogs inhabited these environs, but neither 'Abaset's representations in these two tombs nor the inscriptional epithets which accompany them provide any further information about her relationship with hedgehogs. ${ }^{7}$ Shaikh Al Arab (2019, p. 102) has argued that 'Abaset may have been a nocturnal companion to the solar deity Re-Horakhty and one of his locally worshipped manifestations, the god Banebdjedet, a connection possibly strengthened because of the nocturnal behaviours of hedgehogs. If this was the case, it appears to have been a tradition local to the Bahariya Oasis. A further, obscure Late Period reference to deity with a possible zoomorphic hedgehog-form may be a manifestation of Atum or Osiris-Atum (Lippert 2012, pp. 779-80, 790-91; cf. Ttm: LGG VII, 422 [8]), represented as a mummiform hedgehog crowned with a solar disc. This image occurs once on the north wall of the sanctuary of the Temple of Hibis at the Kharga Oasis (Davies 1953, pl. 3 [register 5]). Given the geographic specificity of these representations and the fact that they are as yet limited to the Late Period, it is not possible to confidently associate these divine associations with hedgehog-related religious practices in the 3rd Millennium BCE.

Generally speaking, animal behaviour was thought to be directly linked to divine mythology by ancient Egyptians (overview: Vernus and Yoyotte 2005, pp. 20-49). A wellknown example is the scarab beetle pushing a ball of dung and orienting itself based on the sun, which was linked by ancient Egyptians to the daily passage and regeneration of the 
sun and associated with the god Khepri (Evans 2010a, p. 15). Hornung and Staehelin (1976, pp. 117-18; cf. Arnold 1994, p. 23) proposed that hedgehogs may have been a symbol of rebirth to the owners of amulets and scarabs, although it is difficult to prove that this association existed in the 3rd Millennium BCE. Rather, during this period, it would seem that the defensive behaviours of hedgehogs were the primary source of inspiration for representations of hedgehogs.

When attacked, a hedgehog first bristles its spines and then rolls into a ball in a highspeed flinch, exposing this mass of pointed spines to the predator in a position which it can hold for several hours (Reeve 1994, pp. 37-39). I argue that this defensive act is distantly evoked in the votive objects which are discussed in this article. Hedgehogs in the wild are resistant to snake venom, scorpion stings, wasp stings, and other noxious substances (Reeve 1994, pp. 87-89, 246). Hedgehogs are also known to seek out other creatures' poisonous secretions, leading them to produce copious quantities of frothy saliva with which they then smear upon their own spines, a behaviour called 'self-anointing' (Burton 1957; Brodie 1977; cf. African hedgehogs: Brodie et al. 1982), although this particular behaviour is not yet known to be represented in ancient Egyptian art. Hedgehogs are also very occasionally represented as hunters in ancient Egyptian art. For example, a hedgehog with a locust or grasshopper clasped in its jaw is included in the 5th Dynasty tomb of Ptahhotep at Saqqara (Harpur and Scremin 2008, p. 303 [detail 153]; discussion: Evans 2010a, p. 124). Because hedgehogs are largely nocturnal creatures, Evans (2010a, p. 128) suggests that this scene may depict a hedgehog hunting at dusk or nocturnally, a situation which was probably observed by ancient Egyptian artists (cf. Evans 2010a, p. 125 n. 99). ${ }^{8}$ It should also be noted that hedgehogs have been observed in captivity and in the wild, including those inhabiting arid regions such as Africa, to ably swim short distances or float in water on their backs while curled in a ball (Reeve 1994, p. 7, pl. 2). It is possible, but cannot be proven, that ancient Egyptians also observed this behaviour in the wild.

Some ancient Mediterranean and northwest African traditions concerning hedgehogs may have had their origin of influence in Egypt (an early study: Buchholz 1965). Unguent vessels in the form of a hedgehog, like the Late Period alabastra and aryballoi found in Egypt (Droste zu Hülshoff 1980, pp. 22-44), are also attested in Archaic period Greece (Webb 1978, pp. 132-34, pl. 21-22), and hedgehogs were a common motif in decorated ceramic products in the late Hellenic period (Mackay 2016). Across the Bronze Age Aegean, ceramic products ranging from kraters to rhyta employed visual motifs that harnessed the defensive behaviour of hedgehogs to curl into a defensive ball when threatened (overview: Leonard 2000, pp. 310-13), and their hides may have even been used in protective headgear of Aegean warriors (Leonard 2000, pp. 313-14). ${ }^{9}$ Comparatively, in astronomical and healing practices in Sub-Saharan Africa, hedgehogs and porcupines have an association with meteorites in Khoisan culture, and hedgehog fat is a key ingredient in amulets worn during curative dances (overview: Snedegar 2008, p. 374). In Northwest Africa, hedgehogs are a source of ingredients for many ailments among Berber tribes, ranging from stomach disorders to protection against the evil eye (Budjaj et al. 2021, p. 14); in particular, hedgehog spines are burned and mixed with other substances in remedies for hair loss. Finally, in Egypt's more recent past, several medical remedies collated by Rushdy (1911) involve

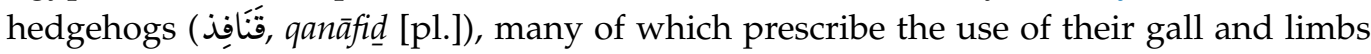
(both dried and fresh) in preventative and curative treatments. The use of hedgehog blood is also named in a healing miracle performed by the Coptic saint Anpa Barsauma al-Uryan, dating to the 14th century CE (MS Paris BnF arabe 72, fols 67b-68b: Tjusi 2016, p. 69).

\section{A Note on Votive Practices}

Studies on ancient Egyptian votive behaviour are numerous; as such, this section directs the reader to the more substantial work on this topic and essentialises some points specific to the late 3rd Millennium BCE and the contexts in which hedgehog-head boat votive objects are attested. The ancient Egyptian practice of dedicating small inscribed and uninscribed objects at temples-including stelae, as well as modelled humans, other beings, 
fauna, and inanimate objects-is sporadically attested for the earliest periods of Egyptian history and this activity flourished at temple shrines towards the end of the 3rd Millennium BCE (overview: Bussmann 2017, 2019). Excavated shrines at Elephantine (Kopp 2018, 2020; Dreyer 1986), Hierakonpolis (Quibell and Green 1900-1902; Adams 1974; cf. McNamara 2008), Abydos (Petrie et al. 1902-1904), Saqqara North (Kawai 2011), Tell Ibrahim Awad (van Haarlem 1998b, 2019; Belova and Sherkova 2002) and Tell el-Farkha (Ciałowicz 2006), spanning much of the known reach of Egyptian settlement in this early period, all attest a rich repertoire of votive objects. These were primarily fashioned from mud, limestone, bone and ivory, and both hard and semi-precious stones (examples: Bussmann 2019, pp. 76-77; Pinch and Waraksa 2009; cf. Wilkinson 1999, pp. 269-70).

The term 'votive' (derived from the Latin votum, meaning 'promise' or 'vow') is frequently employed in reference to Egyptian religious practice (overview: Pinch and Waraksa 2009, pp. 2-7; Pinch 1993, p. 333f.). However, personal gifts to deified beings, which included the revered dead, in the form of a 'votive' seem to have been made in anticipation of blessings or in order to appease a deity, rather than in fulfillment of a vow after a prayer had been answered. ${ }^{10}$ The social setting for these practices is difficult to recreate with any certainty (Pinch 1993, p. 336); there is no clear Egyptian evidence that private individuals were compelled to make offerings of objects to deities outside of the funerary sphere, at least from the period under study in this article. However, the dedication of votive objects is believed to have regularly occurred during particular religious festivals, and private letters from later periods mention people visiting temples at times of personal crisis (Baines 2001). Model figures shown keeling or perhaps even crawling, found within some of the early temple deposits, may evoke the image of individuals who came to the shrines to make offerings (van Haarlem 2019, p. 64; cf. Dreyer 1986, p. 63). ${ }^{11}$

In his work on early ancient Egyptian temples and personal religious practices, e.g., Bussmann $(2006,2011,2013,2015,2017,2019)$ has emphasised the need for careful contextualisation and a diachronic approach to material evidence of religious behaviour in these sacred spaces (cf. Kopp 2020, pp. 100-4; van Haarlem 2019, p. 43f; Kemp 2006, pp. 124-26). A cautious attitude should be adopted regarding the interpretation of objects which may evince pious activity of private individuals (e.g., Baines 1987, 1991, 2017; Weiss 2012; Luiselli 2012; on pilgrimage: Yoyotte 1960), versus that operating on behalf of or at the behest of the state (cf. execration texts: Quack 2002; Baines 2006, p. 8). During the Old Kingdom, most votive objects from temple sites are uninscribed and thus the motivations for offering a particular object are often left unrecorded; votive objects related to hedgehogs are no exception. While the range of votive objects attested is similar across 3rd Millennium BCE temple sites in Egypt (overview: Kemp 2006, pp. 111-31), including hedgehog-head boats, stylistic variation among the corpora and their manufacture featuring locally sourced materials is strongly suggestive of local production for these objects (Bussmann 2011, pp. 750-57; cf. Kemp 2006, p. 141). Wider contextual evidence suggests many votive objects from temples were periodically gathered and placed in secondary deposits (Bussmann 2019, p. 77; at Tell Ibrahim Awad: van Haarlem 2019, pp. 28-41). The practice of gathering and redepositing votive objects is also an important factor affecting how their meaning is interpreted, a point that is re-addressed in the following section. ${ }^{12}$ The evidence resists a sweeping assessment of cult behaviour being the same at all sites.

The iconographic overlap between votive objects and wall reliefs in temple sites and those occurring in non-royal domestic and funerary contexts is minimal during the late 3rd Millennium BCE, especially when compared to the 2nd-1st Millennium BCE (Bussmann 2019, p. 77; cf. Kemp 2006, pp. 111-28). However, hedgehog-head boats are an example of one such overlap in the late Old Kingdom. They occur both in reliefs from decorated funerary chapels in the Memphite cemeteries and in the form of votive model ships deposited in temple sites across Egypt (and one exceptional industrial-domestic site). This overlap, by itself, is not sufficient to explain the meaning and function of hedgehog-head boats and to link the two spheres of representation (cf. Bussmann 2019, pp. 74-75; 2011, pp. 211-12). Figurative votive objects from these sites are varied in their connection to the 
iconography and mythological role of specific deities found elsewhere, and in the case of zoomorphic examples from the Old Kingdom, most cannot be straightforwardly linked to the natural behavior of the animal (cf. crocodile votives: Bussmann 2019, pp. 81-82; frog votives: Kremler 2016). Nonetheless, a pluralistic approach that considers images and material culture from across temple, funerary, and semi-domestic (or industrial) settings, may elucidate meaning(s) which were ascribed to representations of hedgehogs in the round and in relief connected to their ecology.

\section{Hedgehog-Head Boats in the Round and in Relief}

\subsection{Hedgehog-Head Boat Votive Objects}

Palm-sized votive objects in the shape of a model boat with a hedgehog-head prow have been found at sites across Egypt. They form a small part of the growing corpus of documented temple deposits dating to the Early Dynastic period and Old Kingdom, at Elephantine (Kopp 2018, pp. 106-7, abb. 51, pl. 12d-g, 13a; Dreyer 1986, pp. $76-79$ [cat. nos. 202-42], pl. 37-38; cf. in colour: Kopp 2013, figs 14-16), Abydos (Petrie et al. 1902-1904, pl. 11 [241]), Saqqara North (Kawai 2011, pp. 818-19, fig. 11-12) and Tell Ibrahim Awad (van Haarlem 2019, p. 53, pl. 11; 1996; Belova and Sherkova 2002, pp. 138-43). A small number have also been found in the vicinity of the pyramid valley temple at Dahshur (Fakhry 1961, p. 14, pl. 49b), and the most recent example was found in 2014 east of Menkaure's valley temple at Giza (Tavares 2014; Tavares et al. 2014, pp. 553-55, fig. 19). While most examples are made of clay or faience and measure between 5 and $8 \mathrm{~cm}$ in length, the Giza example is carved of limestone and is significantly larger-now $13.9 \mathrm{~cm}$ in length (possibly originally c. $28 \mathrm{~cm}$ : Tavares et al. 2014, p. 554, n. 80). The examples from Dahshur are also comparatively large, and two of the photographed fragments measure $19.5 \mathrm{~cm}$ and $15 \mathrm{~cm}$ in length, respectively (Fakhry 1961, p. 14). The fact that most votives were sized to fit comfortably in the palm may index the importance of holding and touching them as part of any ritual that accompanied their manufacture and deposition, although there is little to confirm this hypothesis in the available evidence.

Comparing selective examples of hedgehog-head boat objects (Figure 3) from Elephantine in southern Egypt, Giza in the Memphite region, and Tell Ibrahim Awad in the Delta region, it is clear that all share the same rudimentary features, even those which are incomplete and damaged. The head of the hedgehog is depicted on the prow (facing backwards) with a snout that turns slightly upwards. The spines are not sculpted or painted on any votive objects found thus far, but this is also true of many representations of live hedgehogs in Old Kingdom tombs. ${ }^{13}$ Some of the votive objects bear structural features that imitate real boats: the cross-beams on the 'deck' and the rudimentary railing are sometimes indicated, and the clearest example of these features occurs in the example from Tell Ibrahim Awad (Figure 3c). Further, in this example, a shallow hole in the middle of one of the beams might be intended to take a mast, although one would expect this depression to be deeper, and surface damage may be a plausible explanation. However, the example can be compared to the centre part of a model-boat fragment found at Dahshur, in which a hole for a single-pole mast is evident (Fakhry 1961, p. 14, pl. 49c). Their identification as boats is further supported by representations of tomb owners and their attendants sailing in such vessels in Old Kingdom funerary art, which is surveyed below in Section 4.2; however, it should be stressed that comparable hedgehog votive objects have never been found in a private funerary context. 


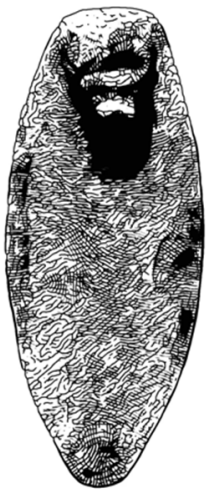

(a)
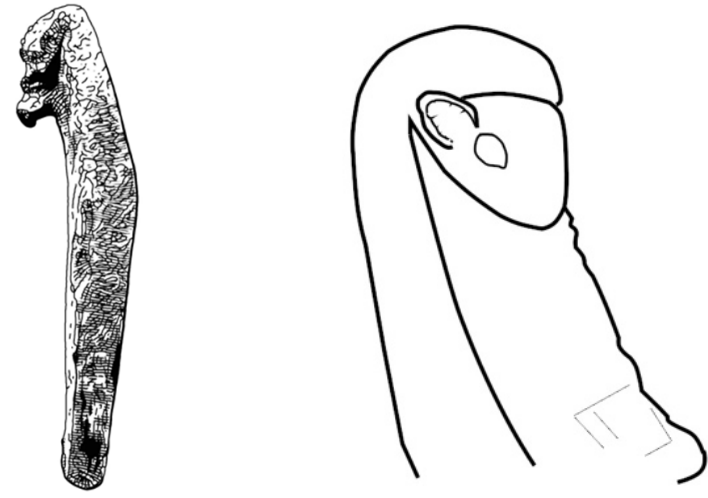

(b)
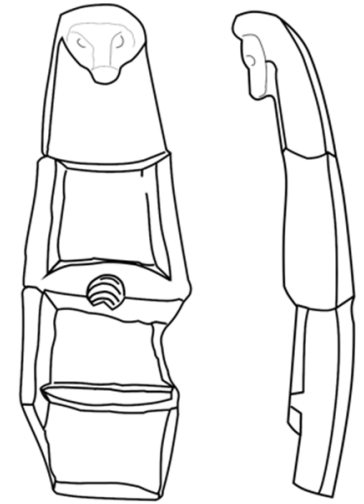

(c)

Figure 3. (a) Faience model hedgehog-head boat found in the temple of Satet, Elephantine. Adapted by author from Dreyer (1986, pl. 37 [202]) (b) Fragment of limestone model hedgehog-head boat found at Giza. Redrawn by author after Tavares et al. (2014, p. 554, fig. 19). (c) Pottery model hedgehog-head boat found at Tell Ibrahim Awad. Redrawn by author after van Haarlem (1996, p. 197, fig. 1).

In the examples of votive objects with a hedgehog-head that do not unambiguously exhibit diagnostic elements of a boat, such as cross-beams, it is plausible to suggest that this motif was nonetheless evoked by the contour of the object-the gentle curve of the plaque mimicking the shape of a boat's hull. In some cases, it is difficult to discern whether the object is a simple model boat or specifically a boat with a hedgehog-head prow, as is the case in an example discovered by Petrie at Abydos (in Petrie et al. 1902-1904, pl. 11 [241]), now in the Ashmolean Museum (AN1896-1908 E.74). ${ }^{14}$ In this example, which Dreyer (1986, pl. 59[d]) included among comparanda to the Elephantine material, cross-beams may be suggested from the modeling of the faience (it is unquestionably a boat), but the prow does not clearly show any features that can be definitively associated with a hedgehog. ${ }^{15}$

The examples which were found in abundance at the Temple of Satet, Elephantine (e.g., Figure 3a) deserve particular comment. The whole deposit from this site is unusual in its level of preservation and its documentation in situ, especially when compared to other sites such as Abydos (McNamara 2008). In total, 47 partial and complete hedgehog-head boat votive objects have been recovered thus far at the site. ${ }^{16}$ This number led excavator Günter Dreyer (1986, p. 79) to tentatively suggest that there was a hedgehog cult or a special devotion to hedgehogs at Elephantine, although this now seems improbable. Bussmann (2019, p. 77) has persuasively argued that the sum of the diverse iconography represented among votive objects at early temple sites, including Elephantine, does not make clear reference to the deities known to have been worshipped at these shrines according to later sources. At Elephantine, no inscriptions or votive objects from any phases of use in the temple indicate a special connection between hedgehogs and Satet or Khnum, or the Elephantine area. The number of hedgehog-head boat votive objects, by itself, is not sufficient evidence of such cults. The further suggestion by Dreyer (1986, p. 79), made earlier by Droste zu Hülshoff (1980, pp. 26-27, 45-46), that hedgehog-head boat votives were dedicated by sailing crews who were resident or passing through Elephantine, is more probable. In such a scenario, a dedicant may have expressed a wish that their riverine journey would be protected before they traveled further south into the dangerous waters of the cataracts. Could such wishes also be reflected in the dedication of boats elsewhere in Egypt, such as North Saqqara, Giza, and Tell Ibrahim Awad? Kopp (2020, p. 100; cf. Altenmüller 2007, p. 21) has proposed that this custom ended, at least in Elephantine, when the state-sponsored expedition leaders from this region became resident there during the 6th Dynasty, rather than in the capital at Memphis, although this does not adequately explain the deposition of hedgehog-head boat votives at other sites. 
Compared to votive objects occurring at temple sites (Elephantine, Abydos, Hierakonpolis, North Saqqara, and Tell Ibrahim Awad), some of which are accepted to be evidence of private religious behaviour within a local temple context (Bussmann 2019, pp. 80-81), the examples that have been found at Dahshur and Giza require a different contextual assessment. The hedgehog-head boat votives at both these sites are not only comparatively larger, but they were also found in the vicinity of royal valley temples attached to pyramids. As the most recent excavations at Giza and Dahshur have shown (e.g., at Giza: Lehner and Hawass 2017, pp. 356-401; Lacovara 2015; at Dahshur: Alexanian and Herbich 2014-2015) towns for the working population who constructed the royal cemeteries and serviced their temples existed alongside the religious sites that were focused on the eternal rejuvenation of the king, and workers of these communities were also buried locally (e.g., at Giza: Lehner and Hawass 2017, pp. 340-43; at Dahshur: Alexanian et al. 2015). The model from Giza shares a close resemblance with the prow of hedgehog-head boats represented in Old Kingdom tomb scenes, and the link between these representations is unquestionable in this case. Fashioning such objects with limestone, rather than faience, reflected the local availability of this material and the skill of artists to work with it. Moreover, the model from Giza was excavated from a sondage in an industrial silo complex, which lead excavators to suggest that a chapel or cult structure may have been located nearby (Tavares et al. 2014, p. 555; Tavares 2014). Tavares and Malak (in Tavares et al. 2014, p. 555) suggest that the presence of votive objects at these sites, like the hedgehog-head boat model, may be indicative of popular piety that not only existed alongside the royal cultic activities present at these sites, but may have also focused on the cultic monuments themselves as their purpose shifted through time. ${ }^{17}$

Several interpretive problems are encountered in the attempt to draw connections from the manufacture and dedication of hedgehog-head boat votives to historical events within the Old Kingdom with any certainty (e.g., at Elephantine: an increase in state-sponsored expeditions into Nubia). The process of gathering and redepositing votive objects into secondary deposits makes it difficult to date more precisely their manufacture, ritual use, and original deposition within the temple environs. However, the dates proposed for most examples fall between the 4th and 6th Dynasties, thus broadly overlapping with the period in which hedgehog-head boats also occur in funerary art and petroglyphs (discussed in Section 4.2). This may suggest a shared origin in meaning concerning the hedgehoghead boat in ancient Egyptian life and religious belief. There is no reason to rule out the significance of these votive objects in private ritual practice extending both before and after this representation from the funerary sphere; in other words, the first manufacture of hedgehog-head boat votive objects may plausibly predate their representation on tomb walls in the Memphite necropoleis from the 4th Dynasty onwards. As Kremler (2016, p. 130) has noted, a prolonged period of manufacture can be established among other zoomorphic figurines in the Elephantine deposit, stretching between the 1st and 6th Dynasties, and she conjectures (Kremler 2016, pp. 130-31, 134) that this may also apply to the manufacture of similar figures from other early temple sites in Egypt.

The broader meaning ascribed to hedgehog-head boats is addressed again in Sections 5 and 6, but some interim suggestions can be offered. The connection between hedgehogs and boats is not immediately obvious. One possibility is that the strength of the protective spines of hedgehogs were desired in the strength of a boat's hull, as initially proposed by Kees (1921, p. 22), evoking the defensive position of a hedgehog when attacked by a predator. Moreover, as noted earlier, hedgehogs in the wild have been observed to swim for short distances and float on their backs while curled inwards, so their association with water in this form is not altogether unnatural. Attempting to link hedgehogs more strongly to sailing, Droste zu Hülshoff (1980, pp. 26-27) tentatively proposed that they could foretell the coming of winds, although this seems largely influenced by Classical authors and cannot be substantiated in ancient Egyptian evidence. ${ }^{18}$ Nonetheless, the suggestion that the votive offerings found at Elephantine pertained to sailing and hunting on the Nile is compelling, given that hedgehog-head boats are represented as river and 
marsh-water vessels in Old Kingdom funerary art of a broadly contemporaneous period. However, it has also been argued, especially by e.g., Altenmüller (2000; 2007, pp. 19-21) that hedgehog-head boats in Old Kingdom funerary art had a particular association with ritual funerary voyages, discussed in Section 4.2. Given the abundance of hedgehog-head boat votive objects at Elephantine, it is notable that representations of this boat do not occur in any of the 6th Dynasty tombs at Qubbet el-Hawa, the elite cemetery of the Elephantine community, although they do occur in a small number of early 6th Dynasty tombs in other provincial cemeteries (Table 1). Could the votive objects have been a substitute for this representation found in elite tombs, or an alternative expression of its meaning through a different medium (cf. Tavares et al. 2014, p. 555, n. 86)? This assumption rests on the understanding that all material forms of the hedgehog-head boat were ascribed the same meaning by ancient Egyptians; yet, as demonstrated, the circumstances around the dedication of hedgehog-head boat votives in temple sites-by and for whom-remain unknown. The possibilities may not have been mutually exclusive: in either scenario, the wish may have been to fulfill a journey by boat (including perpetual journeys in the afterlife) safely.

\subsection{Hedgehog-Head Boats in Old Kingdom Funerary Art}

Hedgehog-head boats occur among the carved and painted reliefs in the decorated tombs of Egypt's most wealthy class of administrators and religious officials, many of whom were buried in the vicinity of the royal pyramids in the cemeteries of Giza, Saqqara, and Abusir (Table 1). In all examples of this boat thus far attested, the hedgehog's head occurs at the prow, facing inwards. ${ }^{19}$ The orientation of the head is particularly distinctive. In the small number of other zoomorphic prows attested elsewhere in art of this period, the animal head faces outwards (e.g., in Niankhkhnum and Khnumhotep: Moussa and Altenmüller 1977, abb. 14); this is a strong indication that the representation mimicked the natural behaviour of the hedgehog curling into its defensive position. No such boat has been discovered yet archaeologically, although its representation is presumed to have been drawn from a real occurrence of boats with the hedgehog-head finial or carved prow. All of the examples occur in non-royal tombs, except in one case from the 4th Dynasty, the tomb of Queen Meresankh III at Giza (Dunham and Simpson 1974, pp. 11-12, pl. 3b, 5a), which may be the earliest known example. A small number of examples are found in provincial elite tombs outside Memphis, at El-Hamammiya, Zawet el-Maiyiten, and Meir (Table 1), whose decoration shows a clear artistic influence from Memphis. Two examples occur on decorated offering tables originating from Giza and Abydos (Table 2). One example has been recently identified by the Yale University Elkab Desert Survey Project (EDSP) in a petroglyph east of Borg el-Hamam, near Wadi Hilal (Table 3), a promising indication that hedgehog-head boats may exist elsewhere as petroglyphs. ${ }^{20}$

All representations date between the 4th and early 6th Dynasties, with the majority dating within the 5th Dynasty. The earliest examples come from Giza, while those which date later largely occur in provincial tombs beyond the Memphite necropoleis. The presentation of data that follows is an update to the catalogues of Altenmüller (2000, pp. 3-19; 2007, pp. 14-18) 21 $^{21}$ and Droste zu Hülshoff (1980, pp. 24-27, 95-118), to which further examples have been added from unpublished or partially published tombs at Giza and Saqqara, as well as in petroglyphs. ${ }^{22}$ The settings in which hedgehog-head boats occur in Old Kingdom tombs can also be loosely grouped into sub-thematic categories (cf. Altenmüller 2000, p. 3), although these are not prescriptive (following van Walsem 2005, p. 51).

1. Hedgehog-head boat being hewn in the shipyard (A)

2. Hedgehog-head boat under sail (B)

3. Hedgehog-head boat being rowed $(\mathbf{C})$

4. Hedgehog-head boat in papyrus-thicket hunting scenes (D)

5. Hedgehog-head boat as transport vessel (including for offerings) (E) 
Table 1. Hedgehog-head boats represented in Old Kingdom tombs.

\begin{tabular}{|c|c|c|c|c|}
\hline Tomb & Theme(s) & Location & Date & Select References ${ }^{23}$ \\
\hline Meresankh III (G 7530) & $\mathrm{C}$ & Giza & 4th Dynasty & $\begin{array}{l}\text { Der Igel no. 46; Dunham and } \\
\text { Simpson (1974), pp. 11-12, pl. 3b, 5a. }\end{array}$ \\
\hline Merib (G 2100-I) & $\mathrm{B}$ & $\begin{array}{l}\text { Giza (now Berlin } \\
\text { ÄM 1107) }\end{array}$ & 4th-5th Dynasty & $\begin{array}{l}\text { Der Igel no. 47; Zorn and } \\
\text { Bisping-Isermann (2011), figs 56, } 58 \\
\text { (cf. Priese 1984, p. } 33 \text { [modern } \\
\text { colour reproduction]). }\end{array}$ \\
\hline Seneb & B & $\begin{array}{l}\text { Giza (now Cairo JE } \\
\text { 51297) }\end{array}$ & 4th-5th Dynasty & $\begin{array}{l}\text { Der Igel no. 63; Junker (1941), } \\
\text { pp. } 61-62, \text { fig. 14b, pl. 4a. }\end{array}$ \\
\hline Iyneferet & $\mathrm{D}$ & $\begin{array}{l}\text { Giza (now } \\
\text { Karlsruhe, } \\
\text { Badisches } \\
\text { Landesmuseum H } \\
\text { 532/1050) }\end{array}$ & 5th Dynasty & $\begin{array}{l}\text { Der Igel no. 66; Schürmann (1983), } \\
\text { pl. 6a-b. }\end{array}$ \\
\hline Nefer [I] (G 4761) & B & Giza & 5th Dynasty & $\begin{array}{l}\text { Der Igel no. 59; Junker (1943), p. 59, } \\
\text { fig, 14, pp. 61-63, fig. } 16 .\end{array}$ \\
\hline Nesutnefer (G 4970) & $\mathrm{C}$ & Giza & 5th Dynasty & $\begin{array}{l}\text { Der Igel no. 50; Kanawati (2002), } \\
\text { p. } 41 \text {, pl. 1a, 15, 52, } 54 .\end{array}$ \\
\hline Senenu $[\mathrm{I}]$ & $\mathrm{E}$ & Giza & 5th Dynasty (?) & $\begin{array}{l}\text { Handoussa and Brovarski (2021), } \\
\text { p. 156, fig. } 70 \text {, pl. 180. Giza Archives } \\
\text { ID: CBE_VI-105 (context); } \\
\text { CBE_VI-107 (detail). }\end{array}$ \\
\hline $\begin{array}{l}\text { Seshathotep [Heti] } \\
\text { (G 5150) }\end{array}$ & $\mathrm{C}$ & Giza & 5th Dynasty & $\begin{array}{l}\text { Der Igel no. 49; Junker (1934), p. } 186 \\
\text { fig. 32; Kanawati (2002), p. 23, pl. } 44 .\end{array}$ \\
\hline $\begin{array}{l}\text { Seshemnefer [I] } \\
\text { (G 4940) }\end{array}$ & B & Giza & 5th Dynasty & $\begin{array}{l}\text { Der Igel no. 51; Kanawati (2001), } \\
\text { pp. 57-58, pl. 34a, 41, 44-45. }\end{array}$ \\
\hline $\begin{array}{l}\text { Kapunisut [Kai] } \\
\text { (G 1741) }\end{array}$ & $\mathrm{E}$ & Giza & 5th Dynasty & $\begin{array}{l}\text { Tomb only partially published (Giza } \\
\text { Archives ID: MFAB_AA2128 } \\
\text { (Context); MFAB_AAW3131 } \\
\text { [detail]). }\end{array}$ \\
\hline Kaninisut [I] (G 2155) & B & $\begin{array}{l}\text { Giza (now KHM } \\
\text { Vienna ÄS 8006) }\end{array}$ & 5th Dynasty & $\begin{array}{l}\text { Der Igel no. 48; Junker (1931), pl. 8; } \\
\text { Junker (1934), pl. 9a-b. }\end{array}$ \\
\hline Akhetmehu (G 2375) & $\mathrm{D}$ & Giza & 6th Dynasty & $\begin{array}{l}\text { Scene unpublished (Giza Archives } \\
\text { ID: A5798_NS; noted in Woods 2015, } \\
\text { p. } 1903 \text { n. 30) }\end{array}$ \\
\hline Akhethotep & $\mathrm{D}, \mathrm{C}$ & $\begin{array}{l}\text { Saqqara (now } \\
\text { Louvre E 10958) }\end{array}$ & 5th Dynasty & $\begin{array}{l}\text { Der Igel no. 60, no. 65; Ziegler (1993), } \\
\text { pp. } 79,132,137-38,199 .\end{array}$ \\
\hline Iymery & $\mathrm{C}$ & Saqqara & 5th Dynasty & $\begin{array}{l}\text { Tomb unpublished. Tomb owner } \\
\text { seated and facing the hedgehog } \\
\text { prow, which Harpur notes is an } \\
\text { unusual variation. }\end{array}$ \\
\hline $\begin{array}{l}\text { Iyneferet [Shanef] } \\
\text { (reused by Idut) }\end{array}$ & B & Saqqara & 5th Dynasty & $\begin{array}{l}\text { Kanawati and Abdel-Raziq (2003), } \\
\text { p. 17, pl. } 35 .\end{array}$ \\
\hline Wa'ti & B & Saqqara & 5th Dynasty & $\begin{array}{l}\text { Tomb unpublished. Hedgehog-head } \\
\text { boat under sail at the south end of } \\
\text { the east wall. }\end{array}$ \\
\hline Nefer and Kahay & A, B & Saqqara & 5th Dynasty & $\begin{array}{l}\text { Der Igel no. 52-52a; Moussa and } \\
\text { Altenmüller (1977), pp. 26-27, pls 1, } \\
\text { 16, 19; Harpur and Scremin (2010), } \\
\text { details 169, 177, 195; pp. 310-11 } \\
\text { (context photograph 4), } 625 \text { (context } \\
\text { drawing 72). }\end{array}$ \\
\hline $\begin{array}{l}\text { Niakhkhnum and } \\
\text { Khnumhotep }\end{array}$ & $C, C, C, E$ & Saqqara & 5th Dynasty & $\begin{array}{l}\text { Der Igel no. 54; Moussa and } \\
\text { Altenmüller (1977), pp. 12, 47, 52, } \\
\text { 90f., 106, 109, pls 6, 8, 12, 30, 41, } \\
\text { abb. } 11 .\end{array}$ \\
\hline Raemka (D 3) & $\mathrm{C}$ & $\begin{array}{l}\text { Saqqara (now } \\
\text { MMA 08.201.1) }\end{array}$ & 5th Dynasty & $\begin{array}{l}\text { Der Igel no. 58; Hayes (1953), } \\
\text { pp. 99-100, fig. } 56 .\end{array}$ \\
\hline
\end{tabular}


Table 1. Cont.

\begin{tabular}{|c|c|c|c|c|}
\hline Tomb & Theme(s) & Location & Date & Select References \\
\hline Khnumhotep (D 49) & $\mathrm{D}$ & $\begin{array}{l}\text { Saqqara (now } \\
\text { Berlin ÄM 14101) }\end{array}$ & 5th Dynasty & $\begin{array}{l}\text { Der Igel no. 64, pl. } 4 \text { (detail); Vandier } \\
\text { (1964), pl. 34, fig. } 435 \text { (context). }\end{array}$ \\
\hline $\begin{array}{c}\text { Ty (reused by } \\
\text { Hemet-Re) (C 15) }\end{array}$ & $\mathrm{C}$ & $\begin{array}{l}\text { Saqqara (now Cairo } \\
\text { CG 1700, CG 1696) }\end{array}$ & 5th Dynasty & $\begin{array}{l}\text { Shoaib (2014), pp. 12-13, figs } 1-2 \\
\text { (context), } 16 .\end{array}$ \\
\hline Ty (D 22) & $\mathrm{C}, \mathrm{E}$ & Saqqara & 5th Dynasty & $\begin{array}{l}\text { Der Igel no. 53-53a; Épron et al. } \\
\text { (1939), pls 19, 24, } 49 .\end{array}$ \\
\hline$[\ldots]$ & $\mathrm{C}$ & $\begin{array}{l}\text { Saqqara (?) (now } \\
\text { Baltimore } \\
\text { WAG 22.87) }\end{array}$ & 5th Dynasty & $\begin{array}{l}\text { Der Igel no. 55; Steindorff (1946), } \\
\text { p. } 78, \text { no. } 263 \text {, pl. } 50 .\end{array}$ \\
\hline Irukaptah [Khenu] & $\mathrm{C}$ & Saqqara & 5th-6th Dynasty & $\begin{array}{l}\text { Der Igel no. 61; McFarlane (2000), } \\
\text { p. 51, pls 2a, 2c, 17, 47-48; Harpur } \\
\text { and Scremin (2017), p. } 64 \text { (detail 72), } \\
68 \text { [detail 78], 179, } 181 \\
\text { (details 72, 78). }\end{array}$ \\
\hline Pernedju & $\mathrm{E}(?)$ & $\begin{array}{l}\text { Saqqara (now } \\
\text { Private Collection) }\end{array}$ & 6th Dynasty & Galán (2000), pp. 148-50, fig. 2. \\
\hline Fetekty (LS 1) & B & Abusir & 5th Dynasty & $\begin{array}{l}\text { Der Igel no. 56; Bárta (2001), } \\
\text { pp. 81-85, figs 3.10-3.12. }\end{array}$ \\
\hline Pepiankh Heri-ib (D 2) & B & Meir & 6th Dynasty & $\begin{array}{l}\text { Der Igel no. 62; Kanawati (2012), } \\
\text { pl. } 82 .\end{array}$ \\
\hline Khunes & $\mathrm{A}(?)$ & Zaweit el-Maiyitin & 5th-6th Dynasty & $\begin{array}{l}\text { Der Igel no. 69; Varille (1938), p. } 15 \text {, } \\
\text { fig. } 5 \text {. Note in this possible example } \\
\text { that the head is not yet modelled. }\end{array}$ \\
\hline $\begin{array}{l}\text { Kakhent }[\mathrm{I}] \text { and Iufi } \\
\text { (A 2) }\end{array}$ & $\mathrm{C}$ & El-Hamammiya & 5th-6th Dynasty & $\begin{array}{l}\text { Der Igel no. 57; El-Khouli and } \\
\text { Kanawati (1990), p. 41, pls 10a, } \\
\text { 11a-b, } 44 .\end{array}$ \\
\hline Kakhent [II] (A 3) & A & El-Hamammiya & 5th-6th Dynasty & $\begin{array}{l}\text { El-Khouli and Kanawati (1990), } \\
\text { p. } 66, \text { pl. } 69 .\end{array}$ \\
\hline
\end{tabular}

Table 2. Hedgehog-head boats represented upon Old Kingdom offering tables.

\begin{tabular}{cclll}
\hline Owner & Theme(s) & \multicolumn{1}{c}{ Location } & \multicolumn{1}{c}{ Date } & \multicolumn{1}{c}{ Reference } \\
\hline Ankhwedjas & E & $\begin{array}{l}\text { Giza (now Louvre } \\
\text { E 25369) }\end{array}$ & 5th-6th Dynasty & $\begin{array}{l}\text { Der Igel no. 67; Vandier (1957), } \\
\text { p. 149f., pl. 11; Mostafa (1982), pl. 31. }\end{array}$ \\
Sekhentiuikai & C & $\begin{array}{l}\text { Abydos (now Cairo } \\
\text { CG 1353) }\end{array}$ & 6th Dynasty (?) & $\begin{array}{l}\text { Der Igel no. 68; Borchardt (1937), } \\
\text { pp. 24-25; Mostafa (1982), pl. 30. }\end{array}$ \\
\hline
\end{tabular}

Table 3. Hedgehog-head boats represented in petroglyphs.

\begin{tabular}{|c|c|c|c|c|}
\hline Owner & Theme(s) & Location & Date & Reference \\
\hline Unknown & B & $\begin{array}{l}\text { East of Borg el-Hamam, } \\
\text { Wadi Hilal. }\end{array}$ & 4th-6th Dynasty (?) & $\begin{array}{l}\text { 'Beyond the Borg el-Hamam-the } \\
\text { Khufu site', fig. } 9 \text { (https:/ / } \\
\text { egyptology.yale.edu/expeditions / } \\
\text { current-expeditions/ elkab-desert- } \\
\text { survey-project/beyond-borg-el- } \\
\text { hamam-khufu-site; accessed on } 4 \\
\text { January 2022). }\end{array}$ \\
\hline
\end{tabular}

All extant examples appear to represent a wooden boat, which in itself is notable given the rarity of native wood in Egypt in the earlier part of the Old Kingdom and the control of its use in shipbuilding (overview: Creasman 2013). This is confirmed in the rare examples of scenes that show the hedgehog-head boat being hewn in a shipyard, as in the 5 th Dynasty tomb of Nefer and Kahay at Saqqara (Figure 4), or the 6th Dynasty tomb of Khakent [II] (Tomb A3) at El-Hamammiya (El-Khouli and Kanawati 1990, pl. 69; cf. Harpur and Scremin 2010, p. 463 n. 293). ${ }^{24}$ Based on the survival of polychrome representations of 
hedgehog-head boats in Old Kingdom tomb reliefs, it could be inferred that the hedgehoghead prow was painted in real life-dark brown for the hedgehog's spines, and possibly a lighter brown for its face and inner ears. In the example from the tomb of Nefer and Kahay (Figure 4), the head of the prow is painted a darker colour to the rest of the boat's outer hull, which is a light ochre. The palette used for the hedgehog-prow can also be compared to other contemporaneous polychrome representations of live hedgehogs, as in the 6th Dynasty tomb of Mehu at Saqqara in which the hedgehog's spines are defined with strokes of dark brown upon a background of ochre or yellow-brown. ${ }^{25}$

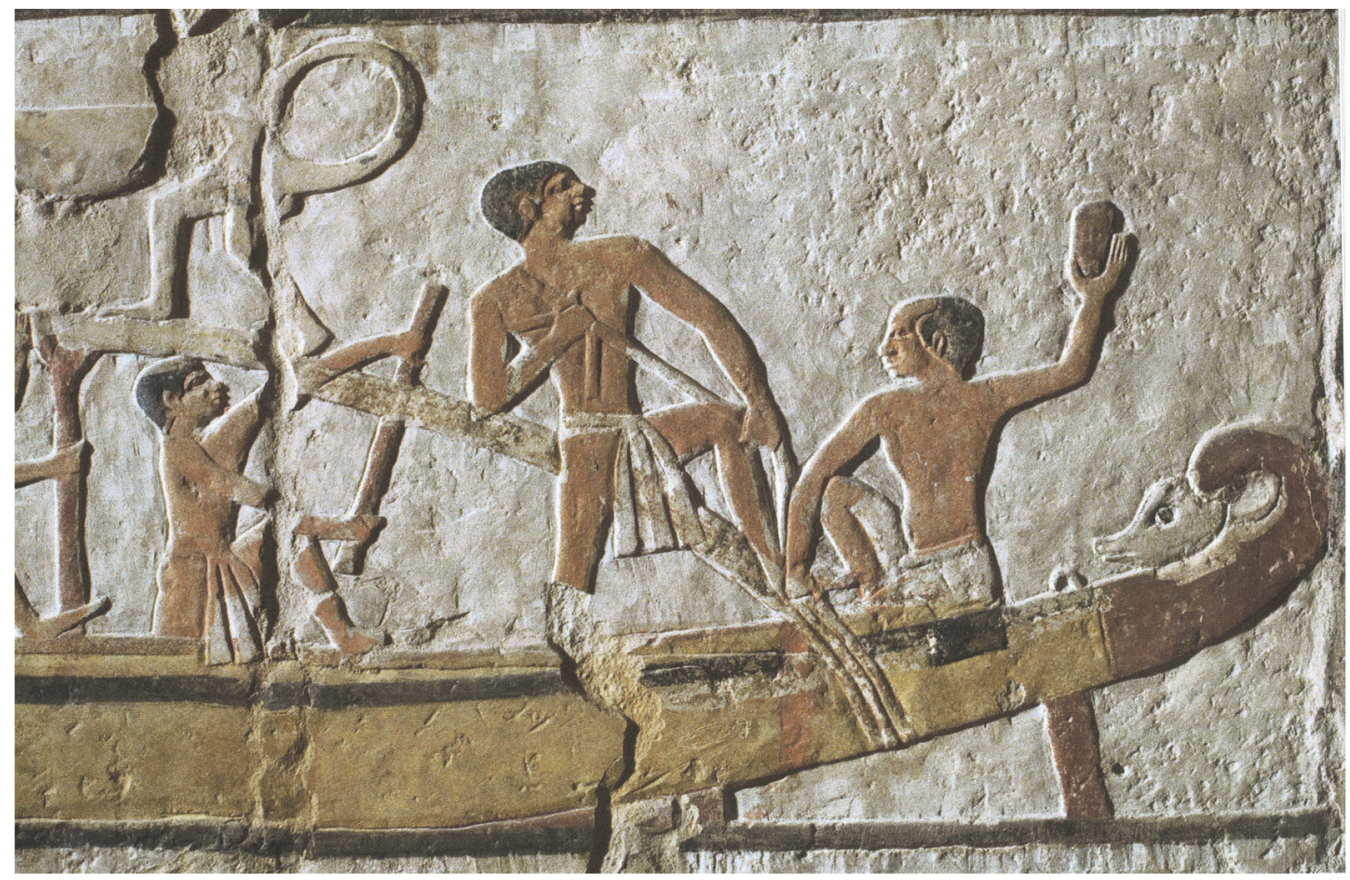

Figure 4. Rare scene detail of a hedgehog-head boat in a shipyard with craftsmen warping the hull. East wall of the 5th Dynasty tomb of Nefer and Kahay at Saqqara (Harpur and Scremin 2010, p. 169 [cf. 177]). Cropped detail adapted from photograph taken by Paolo Scremin. Image reproduced with permission of Yvonne Harpur, Oxford Expedition to Egypt.

One motif that has been the subject of sustained analysis by Altenmüller $(2000 ; 2002 \mathrm{~b}$, pp. 275-8; 2005, pp. 11-14; 2007, pp. 14-15) is the pairing of a hedgehog-head boat, sometimes called hnt or hnt(j) (Hannig I, 850 [21072]), in a convoy with another boat, called $s_{3} 3 b t$, as they travel to and from the Delta region or another otherworldly location. The clearest example of this pairing of a hedgehog-head boat with a š3bt-boat comes from the 4th-5th Dynasty tomb of Seneb at Giza (Figure 5), now in the Cairo Museum (JE 51297; Junker 1941, pp. 62-67, abb. 14a-b). ${ }^{26}$ The hieroglyphic captions accompanying this scene narrate the action of the boats entering a papyrus thicket: 'sailing $(f 3 j t \underline{t} 3 w)$ in the herdsman's boat (hnt mnjw)' and 'rowing (hnt) in the šsbt-boat'. The translation of $h n t m n j w$ is discussed again in Section 5, below.

The broader symbolic meaning of such journeys in Old Kingdom art and their connection to the rejuvenation of the tomb owner in the afterlife have been analysed by Vandier (1964, pp. 738-46), Harpur (1980), Kessler (1987, pp. 74-76), Altenmüller (2002a; 2005, pp. 9-11) and Woods $(2011,2015)$. Such boats in convoy probably symbolized several stages of a journey on the Nile heading northwards to the marshes of the Delta, in order to perform the ritual called $z \check{s ̌ s} w 3 \underline{d}$ (meaning, 'rattling the papyrus') for Hathor, and returning southwards after its completion. Hedgehog-head boats do not appear in any known representations of the žš $w 3$ d ritual in Memphite tombs after the early 6th Dynasty (Bárta 2001, p. 83, n. 164; cf. Seidlmayer 1997, p. 46; Woods 2011, Table 1), although they do occur rarely in provincial tombs of the 6th Dynasty. ${ }^{27}$ Altenmüller (2005, pp. 15-17; 2002b, 
pp. 279-81; earlier: Kessler 1987, p. 83; although cf. van Walsem 2005, p. 74) proposed that the hedgehog-head boat and $\check{s} 3 b t$-boat had particular functions in this ritual voyage: they were 'night and day' boats, respectively, noting especially the examples which feature a figure at the prow of the hedgehog-head boat carrying a torch, as in two 5th Dynasty tombs at Giza: Kaninisut (G 2155, now KHM Vienna ÄS 8006 in Junker 1934, pl. 9a-b) and Kapunisut (G 1741; Giza Archives ID: MFAB_AAW3131). Consequently, Altenmüller argued that the hedgehog-head boat must have held this special role, leading the night ships from the front, because of a hedgehog's nocturnal nature. While a general pattern can be observed in the order of boats in such convoys, depending on whether they are rowed or under sail (cf. Altenmüller 2002b, p. 277), not all scenes can be confidently located as occurring during the night or day, whether through captions or inclusions of men carrying torches, nor do all scenes include a hedgehog-head boat.

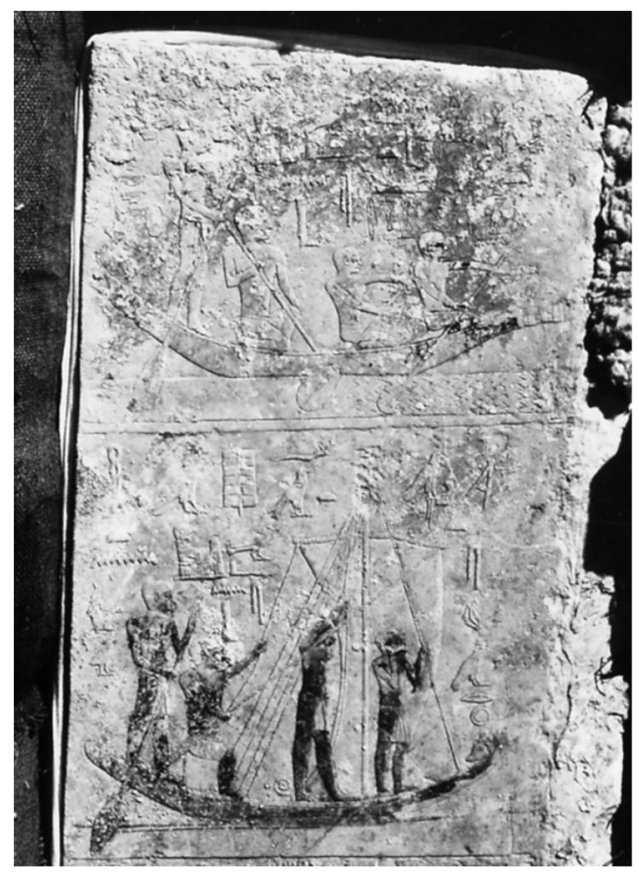

(a)

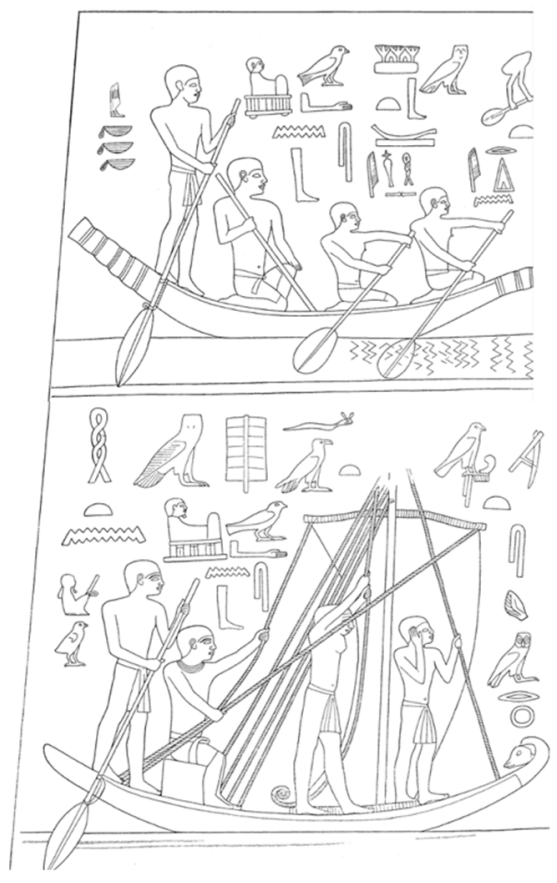

(b)

Figure 5. (a) South outer jamb of Seneb's false door (Cairo JE 51297), with men sailing in hedgehoghead boat in the second register. Detail adapted from digital reproduction in the Digital Giza Archives (KHM_AEOS_II_3089) (b) Line drawing of south outer jamb of Seneb's false-door. Adapted from Junker (1941, abb. 14a-b).

Altenmüller $(2000,2002 b$, 2005) also sought to establish whether the cardinal direction of hedgehog and $\check{s} 3 b t$-boats in convoy could be deduced from their representation, drawing upon a range of supplementary evidence, such as royal and non-royal boat burials and the more expansive description of funerary voyages in the later corpus of Coffin Texts. Altenmüller (2005, p. 17; earlier: 2002b, pp. 281-83) concluded that the motifs of traveling in these boats were directly modeled on the journey of the deceased king across the sky during the night and day. As such, these representations functioned as a conduit for the deceased's journey upon the heavenly Nile, which mirrored such journeys upon the earthly Nile. Some scenes of the tomb owner sailing in convoy are accompanied by captions such as traveling to 'Canal of the West' and the 'Beautiful West' (Altenmüller 2005, pp. 15-16; cf. Altenmüller 2002b, pp. 278-79), which conceivably refer to the realm of the dead and would confirm this hypothesis; however, some of these locations have parallels among hypothesized journeys of the living to the Delta region (Lashien 2009, pp. 102-3). For example, two scenes from the tomb of Kaninisut at (Giza G 2155; Giza Archives ID: KHM_AEOS_8006_36525) provide captions that name the destinations of travel of the convoy: on the east wall, the hedgehog- 
head boat is sailing from Buto in the Delta to an 'offering field' (sht ht $t p$ ) in the south; on the same wall, in the register below, the šsbt-boat sails towards the city of Heliopolis, although its point of origin is not named. Comparable scenes which do not include a hedgehog-head boat include those from the tomb of Kaemrehu (D 2) at Saqqara (Mogensen 1921, pp. 17-18, pl. 6), in which a convoy of ships without a hedgehog-head boat also travels to the Delta region (cf. Altenmüller 2002b, p. 279, n. 55), and the late 5th Dynasty tomb of Khuwiwer at Giza (G 8674 in LD II, pl. 43a-d).

Moreover, hedgehog-head boats without sails also occur in marsh and papyrus-thicket hunting scenes that cannot be connected unequivocally to the žš $w 3 \underline{d}$ ritual (also noted by Bárta 2001, p. 140; on the aesthetics of the hunt: van Walsem 2005, p. 74). Examples of a tomb owner hunting hippopotami in a hedgehog-head boat come from the 5th Dynasty tombs of Iyneferet at Giza (now Karlsruhe Badisches Landesmuseum H 532/1050 in Schürmann 1983, pp. 31-32, pl. 6), Akhethotep at Saqqara (now Louvre E 10958 in Ziegler 1993, p. 79), and Khnumhotep at Saqqara (now Berlin ÄM 14101 in Vandier 1964, pl. 34, fig. 435). ${ }^{28}$ Could the occurrences of hedgehog-head boats in petroglyphs, like the one found near Borg el-Hamam, also recall such voyages to the Delta or to hunting scenes? ${ }^{29}$ Given that no further inscriptions accompany the petroglyph at Borg el-Hamam, the precise motivation for inscribing a hedgehog-head boat at this site remains elusive.

There is considerable variety in the size, including relative number of crew, and structural features of hedgehog-head boats across the settings in which they occur, in some cases even within the same tomb. The boats range from smaller and simpler crafts rowed by two or three men, through to significantly larger vessels with elaborately embellished deckhouses, stern-mounted rudders, and bipod masts with a variety of sails. The latter examples are more clearly suited to riverine voyages when compared to the more simple, single-pole mast boat in the tomb of Seneb (Figure 5). It is possible that the hedgehoghead boat had an earlier origin as a 'herdsman's boat' for travel in the marshes, which is discussed again in Section 5. A particular case-study that is worthy of further comment comes from the 5th Dynasty tomb of Niankhkhnum and Khnumhotep at Saqqara, as three different boats with a hedgehog-head prow are attested within this monument (Figure 6), arguably signaling a distinct function of the hedgehog-head boat in each case.

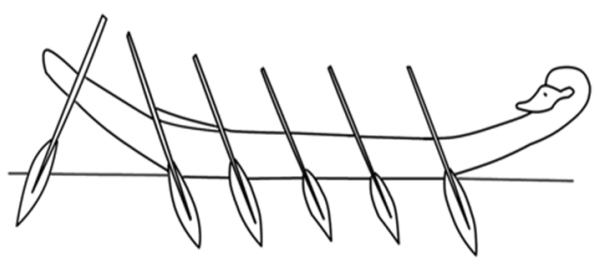

(a)

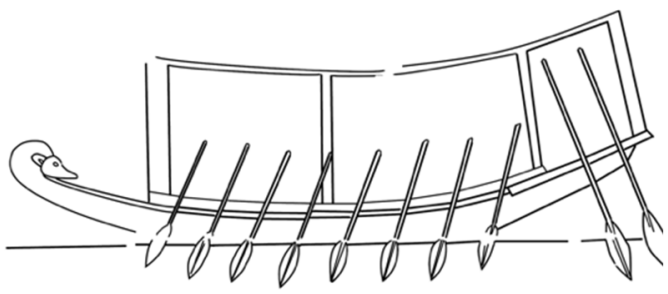

(b)

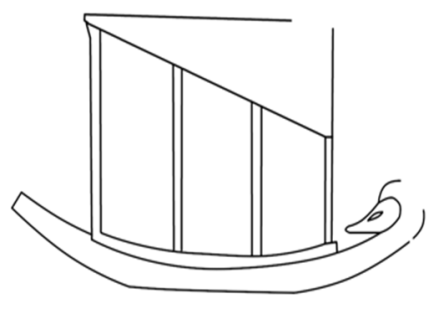

(c)

Figure 6. Examples of boats with hedgehog-head prow in the tomb of Niankhkhnum and Khnumhotep at Saqqara (a) Redrawn by author after Moussa and Altenmüller (1977, pl. 8). (b) Redrawn by author after Moussa and Altenmüller (1977, abb. 11, pl. 30). (c) Redrawn by author after Moussa and Altenmüller (1977, abb. 14).

1. A small boat with six crew (Figure 6a), with a single steering oar, and rowed among a convoy of ships ferrying an enclosed naos 'to Sais', in the entrance portico. The same scene is mirrored on the eastern and western portico walls (Moussa and Altenmüller 1977, pp. 6-8).

2. A larger boat with a decorated deck house (Figure $6 \mathrm{~b}$; compare Figure 7 ), rowed by at least ten men, with two steering oars, and carrying the tomb owner and lector priests, located near the false-door. A hieroglyphic caption accompanying the scene captures the speech of the pilot in the boat behind: 'Keep to starboard! Do not push into our hnt' (Moussa and Altenmüller 1977, p. 91). 


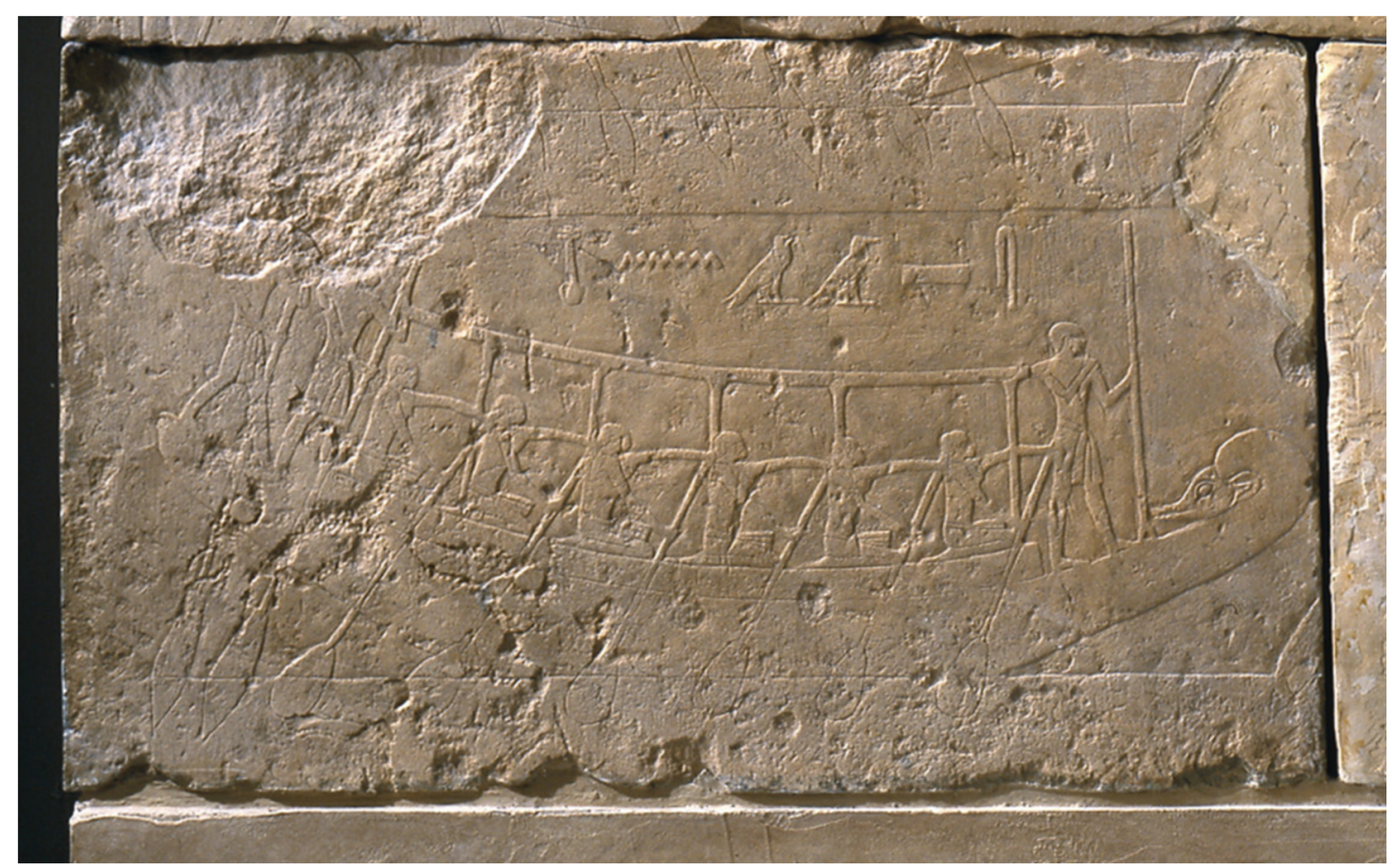

Figure 7. Detail of a hedgehog-head boat being rowed on the south wall of the 5th Dynasty tomb of Raemka, Saqqara, now in the Metropolitan Museum of Art (MMA 08.201.1g). The hieroglyphic caption above reads, 'The rudder is good!' (cf. Junker 1940, p. 59). Image in Public Domain.

3. A small boat with a covered canopy and without crew (Figure 6c), which occurs among a list of boats in association with the magazine for sacred oils, and among other boats with decorated prows, including a hare, long-horned and short-horned cattle, and lotus blooms (cf. Altenmüller 1976, p. 29).

An evolving complexity of the vessels through time, from simpler crafts that were rowed to larger vessels under sail, has already been noted by Landström (1970, p. 35, figs. pp. 95-103). More generally, this may follow the development and innovation in ship construction between the 4th and 6th Dynasties (overview: Stephens 2012; Jones 1995, pp. 36-44; Landström 1970, pp. 35-69; lexicographical analysis: Esposito 2018). Whether the representation of hedgehog-head boats in the tombs discussed indexed this historical development is uncertain and other factors may be at play, including the overall space available in the tomb scene to depict larger and more elaborate vessels. The range may also point to other interpretive possibilities, as raised by van Walsem (2006, p. 300f.), concerning the conscious display of wealth in the Old Kingdom: boats may have been one among many choices of sumptuous motifs to signal such wealth, even though they do not always occur in publicly accessible (or visible) spaces within the tomb, such as the burial chamber. ${ }^{30}$ It is tacitly assumed that the sailing vessels represented in funerary art represent those actually owned by the tomb owner and their estate, although this is difficult to prove in most cases. ${ }^{31}$ Among the corpus for the present article, only a few of the tomb owners had titles that can be connected to professions associated with boats and sailing, for example: Merib at Giza (G 2100-I; now Berlin ÄM 1107), who was an inspector and seal bearer of sacred vessels (Zorn and Bisping-Isermann 2011, p. 83; Zorn 2009, p. 43); and Pernedju, originally from Saqqara (now Private Collection in Galán 2000), who held titles associated with naval administration.

Given the variety of vessels with hedgehog-head prows, further questions arise: did scenes featuring hedgehog-head boats only represent voyages taking place in the afterlife? Or did they (also) recall voyages made during the life of the tomb owner, their inclusion thus enabling such activity to occur in perpetuity? The possibility that the sailing voyages depicted in Old Kingdom tombs may allude to the real occurrence of pilgrimage by ancient 
Egyptian people to sacred sites, for hippopotamus hunting in addition to the žšs $w 3$ d ritual, should not be excluded (Tavares et al. 2014, p. 555; cf. Harpur 1980, p. 59). The reason for choosing a hedgehog-head boat for these voyages is never explicitly stated.

A more cautious interpretive approach is to avoid seeking fixed rules in the representation and function of hedgehog-head boats in Old Kingdom art: the selective use (or absence) of hedgehog-head boats within the wider narrative presented in ancient Egyptian funerary reliefs may not always be meaningful in the ways Egyptologists would hope. What is certain is that no representations of sailing in a hedgehog-head boat are known after the end of the Old Kingdom. From the mid-5th Dynasty, distinguishing discrete ritual functions of individual ships, including those with a hedgehog-prow, becomes difficult because they occur in more diverse pictorial settings (Altenmüller 2005, p. 14; 2007, pp. 19-20). The considerable variety in the depicted structure and size among hedgehog-head boats raises the possibility that several classes of vessels with this prow may have existed in real life, ranging from those suited to shallow marsh-waters to those suited to riverine voyages under sail. Some of these boats may have been especially commissioned for the purposes indicated in funerary art, indicated by the inclusion of scenes of hedgehog-head boats being hewn in a shipyard, as in the tomb of Nefer and Kahay. The transference of ritual imagery of the tomb owner sailing and hunting almost certainly diffused from royal settings (Altenmüller 2002b, pp. 271-74; also concerning magic: Baines 2006, pp. 19-20), yet hedgehog-head boats do not occur among the known repertoire of royal vessels, even if boats with other zoomorphic prows (such as falcons and jackals) are attested (e.g., Mark 2013, pp. 273-74, fig. 5; Early Dynastic period: Berger 1992). As such, an association between hedgehogs and boats probably did not originate from royal iconography related to the king. One possible explanation is that hedgehog-boats already existed among Egyptian watercraft before their first appearance in funerary art of the 4th Dynasty, perhaps as a herdsman's boat for use in the marshes, alluded to in the boat's name which is discussed again below.

\section{On the Name of Hedgehogs and the Hedgehog-Head Boat}

No secure etymology has been proposed for the name of the hedgehog before the 1st Millennium BCE. There is also no certain attestation of the name for hedgehog in Coptic. ${ }^{32}$ In medico-magical texts, such as P. Ebers and P. Edwin Smith, the words hnty (Wb. III, 121 [15]) and hnt3 (Wb. III, 122 [7]) are usually translated as hedgehog, although they may also refer more generally to a 'spiny creature', which could include porcupines (Droste zu Hülshoff 1980, pp. 13-16; Vernus and Yoyotte 2005, p. 146). Even though hedgehogs and porcupines were distinguished by Egyptian artists, the ancient Egyptian name for a porcupine (if it was different to that of a hedgehog) is unknown. In the case of P. Ebers, discussed earlier in Section 2, is interesting to note that different spellings of the word, hnt3 (1. 66.12) and hnty (1. 92.17), are present in the one papyrus in two remedies, and that each remedy uses a different term for the spines of the hedgehog ( $\check{n} n j$ 'hair', in the former; srt 'spine', in the latter). Because the prescriptions in P. Ebers are presumed to have been collated from several sources (Popko et al. 2021, pp. 35-36), the discrepancy could be explained this way.

Both hnty and hnt3 are composed with the hieroglyphic sign 4 [Gardiner M2], representing a sharp, pointed marsh plant which also provides the phonetic part $h n$. Ordinarily, this is a sign used in the names of plants such as hnj (Hannig I, 837 [20759]), meaning 'rush' or 'reed'. In the case of the name for a 'spiny creature', the orthography may have also visually reinforced the allusion to the spines of a hedgehog or a porcupine. The word is also commonly classified with the sign ? [Gardiner F27], with the sense of HIDE. Thus, the orthography of the name for this creature underscored this particularly distinctive feature of its physical appearance. A further possible appearance of a word determined by a hedgehog-sign was proposed for one orthographic spelling of $t n b h$ 'to turn away, to shrink, to wander' (Hannig II, 2700 [37203] in the Eloquent Peasant (B 1, 127 [P. Berlin 3023, 1. 97]; Gardiner 1923, p. 23), which dates to the second half of the 12th Dynasty, c. 1818 BCE or later (overview: Parkinson 2002, p. 297). Gardiner (1969, p. 113) proposed that the 
verb may allude to the natural actions of the hedgehog. However, Parkinson (2012, p. 106) suggests this hieratic sign in P. Berlin 3023 is a pig which is otherwise unknown in the hieroglyphic sign corpus, and that the word in context may metonymically evoke an unclean animal.

The name for hedgehog is not yet known to be attested in the written record for the 3rd Millennium BCE, even though hedgehogs are well known in art of this era (Gerke 2017, pp. 78-79). Droste zu Hülshoff (1980, p. 45) tentatively suggested that a taboo may have existed for the name of the hedgehog due to its nature as an animal with the power to ward-off evil; however, the absence of naming captions for fauna and, indeed, people in Old Kingdom art is common, as discussed by Gerke (2017, pp. 80-82). ${ }^{33}$ One Old Kingdom etymology has been proposed by Altenmüller (in Moussa and Altenmüller 1977, p. 90, n. 423, pp. 91-92), linking the words hnty or hnt3 to the name for a small watercraft, the so-called hnt(j)-boat (Hannig I, 850 [21072]; Jones 1988, p. 142 [33] expresses doubts). While Hannig restores $-j$ to the end of $h n t$, it is never present in the attestations of the word known thus far in the Old Kingdom, which are noted below. A reappraisal of the lexeme hnt in Old Kingdom sources does not further support Altenmüller's theory, but it offers clues to the original purpose of this curious sailing vessel. Specifically, hnt may be related to words associated with marsh-water habitats.

The words hht or hnww, meaning 'watercourse' or 'marshy lowland' (Hannig I, 838 [20834]), as well as hnj for 'rush' or 'reed' (Hannig I, 837 [20759]), are all attested in Old Kingdom sources with the sign representing the sharp, pointed marsh plant [Gardiner M2]; as such, they may be closely related to the name given to the boat which traverses them. This could be compared to other boat names such as the š3bt-boat, also described in Section 4.2, the orthography and meaning of which is closely bound to its material properties (papyrus and the $\check{s}_{3} b t$-plant) as well as their purpose (to sail among papyrusplant habitats). It is important to note that scenes which include inscriptional captions naming the hedgehog-head boat are the exception in the Old Kingdom and not the norm. Comparatively, the name of the šsbt-boat is more widely attested (Jones 1988, p. 146 [71]). Only four tombs as yet known include the lexeme $h n t$ in the captions next to a hedgehoghead boat, in which it is usually referred to with a first-person (pl.) suffix pronoun ('our hnt'; i.e., belonging to the crew): Seneb at Giza (Junker 1941, pl. 4 [a]); Senenu at Giza (Giza Archives ID: CBE_VI-107; cf. Handoussa and Brovarski 2021, p. 156, fig. 70, pl. 180), Fetekty at Abusir (Bárta 2001, pp. 83-84, figs 3.10-3.12); and Niankhkhnum and Khnumhotep at Saqqara (Moussa and Altenmüller 1977, pl. 30; Harpur and Scremin 2010, p. 182 [195]). None of the attestations of the word hnt are classified with a sign of a ship, as is found in other captions which include boat names, like the š3bt-boat (Hannig I, 1281 [32162]), or for smaller crafts such as papyrus-plant skiffs (e.g., jnp: Jones 1988, p. 130 [8]; snbt: Jones 1988, p. 140 [63]) and floats (e.g., hnk: Jones 1988, p. 142 [52]; zhn: Jones 1988, p. 145 [66]; overview: Esposito 2018). In the case of $h n t$, the lack of a such a sign could be explained by context because the captions occur close to the image and the sense of BOAT may be supplied from the scene, although it is curious that the $\breve{s} 3 b t$-boat is given this further classification more regularly.

A further layer of meaning may be deduced from the co-text in which hnt occurs. In an earlier comment on the caption from the tomb of Seneb (Figure 5a,b), Junker (1941, p. 64) offered a reading of f3jt t3 $w m$ hnt mnjw 'Sailing (lit. carried by the wind) in a herdsman's boat'. ${ }^{34}$ The lexeme mnjw, meaning 'herdsman' (Hannig I, 520 [12927]), is particularly interesting because it may have classified the type of boat depicted. ${ }^{35}$ The word is composed with the sign 6 [Gardiner A47], probably representing a seated herdsman wrapped in a cloak. Subsequently, Junker (1941, pp. 63-64) describes the hedgehog-head boat as a 'little sailing boat', noting especially the small number of crew (three) and that it is depicted with a simple, single wooden pole-mast. This is reinforced in the distinctive orthography of the word $t 3 w$ (air; wind) in the same caption (compare: $t 3 w$ in Hannig I, 1442 [37716, 37717], using ${ }^{3}$ [Gardiner P5]). ${ }^{36}$ Junker (1941, p. 64f.) thus conjectured that this boat was probably used by herdsmen in the marshes of the Delta and upon small 
canals, but probably not in deeper waters. Junker's conclusion is compelling, and this may add strength to the etymological connection between the names of these marsh plants and the hedgehog-head boat proposed in this article as, in many cases (but not all), the hedgehog-head boat is shown being rowed or under sail in lowland waters and canals (i.e., those called $h n t$ and $h n w$ ); as such, this may have been its original purpose. If the link between $h n t$ (boat) and $h n t / h n w$ (marshland, watercourse) is accepted, it may also provide a new meaning to the rare personal name from Dara in Middle Egypt, Hnt-n(yt)- $\mathrm{H}_{n} m w$ (Scheele-Schweitzer 2014, p. 544 [2442]), perhaps thus meaning 'The henet of Khnum', which had previously been translated as 'The freshness (of breath?) of Khnum'. This would be the only confirmed association between the lexeme hint and one of the Elephantine deities, Khnum, in this period. ${ }^{37}$

Although linking the Old Kingdom lexeme hnt to the later words for a 'spiky creature', such as hnty and hnt3, cannot be further substantiated, the hypothetical origin of the hnt-boat as one used by herdsman in the marshes may offer a fresh perspective on the hedgehog-head prow, if such boats were crafted with components (such as the prow and hull) which were imbued with apotropaic properties related to the defensive behaviours of hedgehogs. Such an association may tentatively be likened to other visual representations of protective magic performed by herdsman in boats in Old Kingdom tombs, which included uttered conjurations with accompanying gestures while fording cattle and being cloaked in special garments (e.g., Ogdon 1987, 1989; Meyer 1990; van Walsem 2005, p. 89; recently on 'water conjurations': Gundacker 2019; generally on magic in this period: Baines 2006). A boat of this nature, offering protection to its crew, may have thus been ideal for dangerous voyages, including those representing hunting by the tomb owner in the late-5th Dynasty.

\section{Linking the Two Spheres: Hedgehogs and Hedgehog-Head Boats in Art and Religious Practice}

The broader significance of boats in ancient Egyptian daily life and ritual practice is undeniable. It was during the Old Kingdom that Egypt became a 'full-fledged nautical power' (Vinson 1994, p. 21), a sumptuous display of which occurs in the reliefs of seafaring ships in 5th Dynasty king Sahure's pyramid causeway (Mark 2013; El Awady 2009). However, the significance of boats to people living on the Nile, and the associated dangers of traversing and hunting on the Nile, is communicated in the earliest expressions of Egyptian art and writing (Vanhulle 2018a, 2018b; Lankester 2013; earlier: Vinson 1994, pp. 11-20; Berger 1992; Landström 1970, pp. 11-25; in Sudan: Cooper and Vanhulle 2019). In addition to the evidence already surveyed, it should be noted that from the reign of 5th Dynasty king Neferirkare onwards, miniature boat models were essential elements of cultic equipment in both royal and non-royal burials (Creasman and Doyle 2015, pp. 93-94; Verner 1992; an overview on models: Tooley 1995, pp. 51-56), although as yet, hedgehog-head boat models have not been found among this corpus. The practice of ritually dedicating boats in other settings is also well attested, including graffiti in sacred monuments and in petroglyphs in Egypt's desert regions (overview: Vanhulle 2018b; Lankester 2013; cf. the 'boat tableau' at South Abydos: Wegner 2017, pp. 17-22, 26-28). Hedgehog-head boats, whether in relief on a tomb wall, as petroglyphs, or as modeled objects, are not found after the Old Kingdom. It is possible that as religious practices evolved, the specific purpose of visually depicting the hedgehog-head boat in the tomb or manufacturing votives in their form was lost, replaced with other material forms of protective magic for sailing.

An expansive role of the hedgehog as a protective creature can be proposed with further evidence from the Old Kingdom corpus of funerary art. An important motif that is contemporaneous to the representations of hedgehogs discussed in this article is that of live hedgehogs being carried in cages from the tomb owner's funerary estates, or by hunters returning from the desert with game (as in Figure 1a; catalogue: Droste zu Hülshoff 1980, pp. 81-90). As many as four could be packed into a small carrying cage, as in the example from the 6th Dynasty tomb of Neferseshemptah at Saqqara (Figure 8). They are usually carried by men, although in one example, from the late 5th Dynasty tomb of 
Ty at Saqqara, a hedgehog is carried by a female personification of the funerary estate (Épron et al. 1939, pl. 106). Most of these representations occur in the 5th-6th Dynasty tombs of Memphite officials at Giza and Saqqara, although a few have also been recorded in provincial tombs, such as Pepiankh at Kom el-Ahmar (Brodrick and Morton 1899, p. 31). As yet, the only known occurrence of this motif in the Middle Kingdom comes from the tomb of Khnumhotep II at Beni Hassan (Kanawati and Evans 2014, pl. 140), and two further examples are known from the Late Period (Droste zu Hülshoff 1980, pp. 91-92). ${ }^{38}$ While some animals were evidently brought alive to the tomb to be slaughtered for offerings (such as gazelles, fowl, and hares), some of which were spoils from the desert hunt, hedgehogs never appear in piles of offerings, nor are they named in the tabulated offering lists in Old Kingdom tombs. ${ }^{39}$

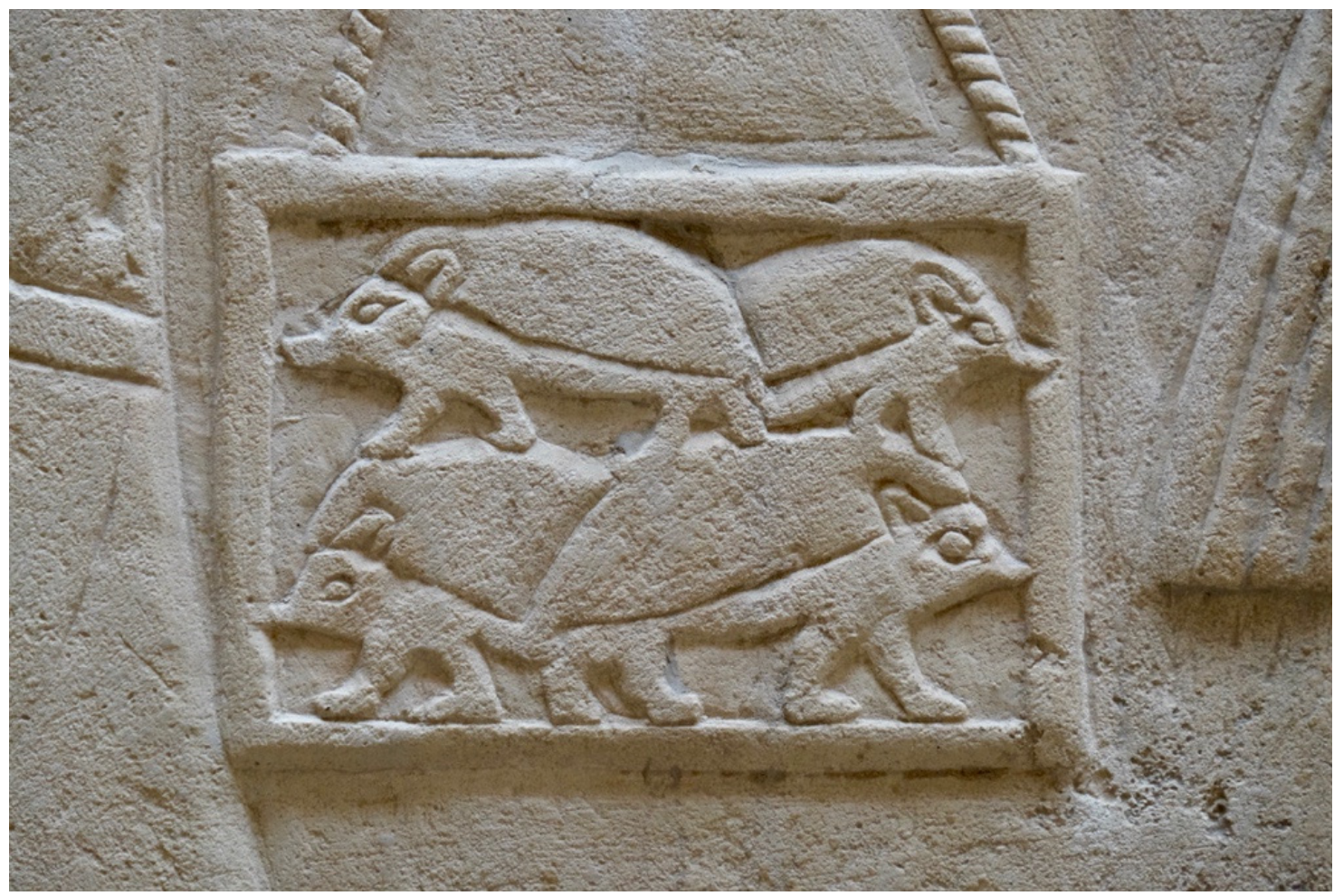

Figure 8. Detail of four live hedgehogs inside a small cage with a coiled rope handle, carried by a male offering bearer. West wall of room two in the 6th Dynasty tomb of Neferseshemptah, Saqqara. Photograph by author (January 2019).

It has already been stated as unlikely that hedgehogs formed a regular part of the ancient Egyptian diet, and evidence beyond Old Kingdom funerary scenes for other wild desert animals, such as hyenas, being eaten is minimal (Ikram 1995, pp. 22-23), although it cannot be wholly excluded that they were eaten occasionally (cf. Fitzenreiter 2009, pp. 320, 330-31). I favour the possibility that hedgehogs carried to the tomb played another role in addition to being an offering: while alive, they may have acted as a deterrent to dangerous and unwelcome creatures such as scorpions and snakes, which posed a threat to the tomb owner including in their representational form. ${ }^{40}$ From a different setting and from much later periods of Egyptian history, such a function has already been tentatively assigned to scaraboid hedgehog amulets (e.g., Figure 2a), which were closely linked with the natural behaviour of hedgehogs described in Section 1. These amulets could be inscribed with images of snakes or scorpions on their bases, and the possession of such an object was intended to protect its owner from bites and stings (Droste zu Hülshoff 1980, p. 43). Could hedgehogs, like those carried in cages in funerary art, have been kept alive in order to be released in cemeteries located at the desert edge for protection against unwanted, 
dangerous stinging and biting creatures? Further, could a boat modeled in the form of a hedgehog have been thought to symbolically offer this same protection to its owner and its crew?

Related to this protective role that emphasized a hedgehog's hunting abilities, a tentative connection could also be drawn to watery habitats and thus to their association with boats: hedgehogs' natural predation of scorpions may have also been thought to extend to the stings of giant waterbugs (Belostomatidae). Evans and Weinstein (2019) have noted that ancient Egyptians seemingly considered waterbugs analogous to scorpions due to their visual and behavioural similarities, further evidenced in their association with the scorpion-goddess Serket (Spieser 2001). In particular, waterbugs thrive in marshes and slow-flowing streams, the same habitat in which the hedgehog-head boat may have been hypothetically first used. In this respect, waterbugs (and scorpions) may have been conceived as being comparable to other creatures that inhabit both desert and Nile habitats such as snakes, which were occasionally called jmy-t3-mw, meaning 'those who are on the earth and in the water' (TLA lemma-no. 500045: Gerke 2017, pp. 83-84). ${ }^{41}$ There is little in the evidence to confirm this hypothesized connection between hedgehogs and scorpion-like creatures that inhabited the Nile. Yet such conceptual associations between the desert and the Nile are plausible and have been proposed for other material productions (notably modeled boats and boat petroglyphs) that seemingly bridge these habitats in the ancient Egyptian world with their imagery, especially through animal and hunting symbolism (e.g., Maydana 2021; Vanhulle 2018b; Lankester 2013, 2016; Berger 1992).

An ecological link between hedgehogs and water that may explain their association with boats is not easily drawn. The natural behaviour of hedgehogs, namely their predation of snakes and scorpions, may have made them ideal companions in boats as deterrents for dangerous and unexpected stowaways in sailing voyages, a role which I propose they may have played in cemeteries. Moreover, their predation of scorpions may have been thought to extend to another stinging creature, the waterbug, possibly thought to be scorpionlike by ancient Egyptians. It remains plausible that a boat with a hedgehog prow could have been favoured in night-time sailing journeys given the hedgehog's nocturnal nature, although I have demonstrated that hedgehog-head boats were not exclusively linked to the representation of voyages taking place in darkness in funerary art; on the contrary, they are also included in depictions of activities that would naturally require light, particularly the hippopotamus hunt. The most likely interpretation is a very broad one: that these vessels summoned 'prickly protection', to quote Tavares (2014), while sailing upon the water. They recalled the defensive position of a hedgehog exposing its spines to a predator, which offered a safeguard to the interior-for the hedgehog, its vulnerable underbelly, and for the boat, its crew, passengers, and load. The precise origins of the hedgehog-head boat remain elusive, but the name hnt which was given very occasionally to these boats in scene captions may index its close association with small boats used by herdsmen in lowland and marsh-waters.

In summary, the representation of these distinctive boats in relief and in the round alluded to the perils of sailing and hunting upon the Nile and the important protective role that hedgehogs played in confronting these dangers. The specific image of a hedgehog-head boat is no longer attested after the end of the Old Kingdom, but the defensive behaviours of hedgehogs were still recalled by other means in the abundance of objects that took their form in later periods of Egyptian history.

Funding: This research received no external funding.

Institutional Review Board Statement: Not applicable.

Informed Consent Statement: Not applicable.

Acknowledgments: I am indebted to Yvonne Harpur who shared her notes on representations of hedgehogs in Old Kingdom art, especially those currently unpublished at Saqqara. I also especially thank Linda Evans, Ana Tavares, and Michael Zellmann-Rohrer, who shared references, literature, 
and their expertise at different points in this article's progress. I also thank Inês Torres and two anonymous reviewers for their comments and corrections; other mentions of thanks are included throughout the article in footnotes. This article began as conference paper presented at AMPHORAE VII at the University of Sydney in 2013 but was significantly expanded and rewritten during the COVID-19 pandemic between 2020-2021. Every effort has been made to consult relevant references and any significant omissions in literature remain my own fault.

Conflicts of Interest: The author declares no conflict of interest.

\section{Abbreviations}

Baltimore WAG Walters Art Museum (formally Gallery), Baltimore.

Berlin ÄM Ägyptisches Museum und Papyrussammlung, Berlin.

Cairo CG Catalogue General, Cairo Museum.

Cairo JE

Gardiner

Journal d'Entrée, Cairo Museum.

Hannig I

Enumerated sign-list in Gardiner, Alan H. 1957. Egyptian Grammar. Oxford.

Hannig, Rainer. 2003. Ägyptisches Wörterbuch I: Altes Reich und Erste Zwischenzeit. Kulturgeschichte der Antiken Welt 98. Mainz.

Hannig II Hannig, Rainer. 2006. Ägyptisches Wörterbuch II: Mittleres Reich und Zweite Zwischenzeit, 2 vols. Kulturgeschichte der Antiken Welt 112. Mainz.

$\mathrm{L} D$

LGG Lepsius, Carl Richard. 1897-1913. Denkmäler aus Aegypten und Aethiopien. Leipzig.

KHM Leitz, Christian (ed.) 2002-2003. Lexikon der ägyptischen Götter und Götterbezeichnungen. Orientalia Lovaniensia Analecta 110-116, 129. 8 vols. Leuven. Kunsthistorisches Museum, Vienna.

MMA

Paris BnF $W b$ Metropolitan Museum of Art, New York. Bibliothèque nationale de France, Paris. Erman, Adolf, and Hermann Grapow (eds). 1926-1961. Wörterbuch der Aegyptischen Sprache. 7 vols. Berlin.

\section{Notes}

1 A small number of slate palettes (Petrie's so-called 'pelta' palettes) dating to the mid-4th Millennium BCE (Naqada I through to Naqada IIc-d periods) have been proposed to represent stylised hedgehog-heads by Brovarski (2015), although none of the diagnostic features of hedgehog representation (such as spines or a pointed snout) can be discerned. That they have a zoomorphic form remains questionable. With thanks to Matthew George for discussing the interpretation of these palettes with me.

2 With thanks to Yvonne Harpur for this observation.

3 This can be compared to the representation of insects, such as butterflies and grasshoppers (e.g., Evans and Weinstein 2019; Evans and Nazari 2015; Evans 2015, with bibliography).

4 As Forshaw (2014, p. 30) notes concerning P. Ebers, magical incantations ('utterances') were probably expected to accompany most prescriptions including during their preparation, even though they are not specifically listed against every remedy (cf. Popko et al. 2021, pp. 38, 44-46).

5 Although a curious example of a representation of a swaddled (possibly mummiform) hedgehog with a sun-disc at the Hibis Temple at Kharga Oasis is discussed below (overview: Lippert 2012).

$6 \quad$ Her name perhaps meaning 'Praising Isis' (Sherbiny and Bassir 2014, pp. 174-76), although other readings of the name are possible (Lippert 2012, pp. 789-90).

7 It is interesting to note that the so-called 'hedgehog-headdress' worn by 'Abaset in the tomb at Fama has been painted with a bright blue pigment (Shaikh Al Arab 2019, p. 89, fig. 5, pp. 91-92), which Shaikh Al Arab suggests imitated lapis lazuli. Another tempting possibility is that this colour referenced the blue hues of faience, of which almost all vessels in the shape of hedgehogs were fashioned from by this period in Pharaonic history. However, because this blue pigment is used extensively elsewhere in the tomb, including in the headdresses of other deities such as the scarab headdress of the god Khepri, it is problematic to argue such a direct connection.

8 Locusts and grasshoppers, more generally, are associated with periods of agricultural collapse (Latchininsky et al. 2011), and their possible proliferation may have indexed ecological changes at the end of the 3rd Millennium BCE (cf. on beetles: Bárta and Bezděk 2008; on representations of ecological change in this period: Burn 2021). As such, one possible interpretation of a hedgehog hunting invertebrates could be that of a visual metaphor for agricultural prosperity. However, it is also worth noting Evans and Weinstein's (2019) observation that negative illustrations of invertebrates are often lacking in the artistic corpus for the 
3rd Millennium BCE, and ancient Egyptian artists fashioned decorative pendants and other bodily adornments with images of locusts.

However, hedgehogs also seem to have acquired an association with being a 'sinister and baneful creature' in ancient Greece (overview: Mackay 2016; cf. in Judaic traditions: Foster 2002, p. 298).

Some theophoric ('oracular') personal names given to children may be speculative evidence of the latter (Vittmann 2013, p. 2; Baines 1987, pp. 95-97).

In some places, like Tell Ibrahim Awad, models of shrines themselves were also dedicated (van Haarlem 1998a).

E.g., objects fashioned with iconographic associations with kingship (e.g., falcons, mace-heads, and statues of kings), which perhaps pertained to state-required or state-sponsored ritual (e.g., McNamara 2008; Wengrow 2006, p. 134), may not have been originally dedicated in the same event (nor in the same period) as those which seem to relate to 'private' concerns (e.g., Kopp 2020, p. 22; Bussmann 2019, p. 77).

When a hedgehog's spines are modeled in art of this period, which is not always the case, they can be carved (e.g., in Mereruka, Saqqara: Kanawati et al. 2010, pl. 39 [b]), or indicated in paint through a stippling effect or with brush strokes (e.g., in Khnumhotep II, Beni Hassan: Kanawati and Evans 2014, pl. 36 [b]). An example from the 6th Dynasty tomb of Mehu is described below.

With thanks to Liam McNamara for permission to consult this example in person, and for sharing his thoughts about the object's possible date and identification.

Votive modeled boats without zoomorphic prows are attested elsewhere, including among the shrine deposits at Elephantine (e.g., Kopp 2018, pp. 107-8, pl. 13 [b-d]; Dreyer 1986, pp. 121-27, figs 35-36, pl. 40), Tell Ibrahim Awad (van Haarlem 2019, p. 53), and Saqqara North (Yoshimura et al. 2005, pp. 371, 373, fig. 9, pl. 52b). An exceptional example from Tell Ibrahim Awad of a 'company of baboons' on a boat is unlikely to be related to hedgehog-head boat votives (van Haarlem 2019, p. 53; Belova and Sherkova 2002, pp. 165-77).

41 were originally published by Dreyer in 1986, to which 6 further examples can be added from more recent publications of material from the temple (Kopp 2018, pp. 106-107, abb. 51, pl. 12d-g, 13a).

In the case of Dahshur, the valley temple of the Bent Pyramid appears to have served the local community as a cult-centre in later periods, including the popular worship of the deceased king Sneferu (Bussmann 2019, p. 77; cf. Kemp 2006, pp. 207-209) and such practices have also been documented at Abusir (Morales 2006).

Droste zu Hülshoff (1980, p. 27 n. 1) notes especially: Aristotle (Historia animalium, 9.6), Plutarch (De sollertia animalium, 28), and Pliny (Historia Naturalis, 8.56).

An exceptional example occurs in the 6th Dynasty tomb of Pepiankh Heri-ib at Meir (Blackman 1924, pl. 16), in which a boat under sail is depicted with hedgehog-heads facing inwards at both prow and stern.

A further example may be a petroglyph from Rod el-Air, Serabit el-Khadim, in South Sinai (Tallet 2012, pl. 58 [doc. 97]), of a boat with a square deckhouse and an animal on a standard that could conceivably be a hedgehog, although Tallet (2012, p. 93) proposed this animal to be an Egyptian mongoose (Herpestes ichneumon). It is difficult to identify the mongoose in Egyptian art with any certainty (cf. Evans 2010b); despite the pointed ears and rounded body that make a hedgehog identification tempting, the length of tail suggests another creature. A further possibility is that the creature on this boat is the jackal- or fox-like Wepwawet, also known to appear on standards emerging from its den (Evans 2011, pp. 104-6, fig. 1). With thanks to Julien Cooper for the reference to the South Sinai corpus.

Kaemsekhem (G 7660), which was included by Altenmüller (2000, p. 4 [Dok. 3]), is excluded here because a hedgehog-head ship cannot be confirmed in this tomb (cf. LD II, 32; 'G 7660', http:/ / giza.fas.harvard.edu/sites/1271/full/ [accessed on 5 January 2022]).

I am indebted to Yvonne Harpur for sharing her notes concerning hedgehogs and hedgehog-head boats that occur in tombs at Giza and Saqqara and elsewhere, including the unpublished tombs of Iymery and Wa'ti at Saqqara.

References to Droste zu Hülshoff's (1980) catalogue are provided in the first instance (abbreviated 'Der Igel no. [X]'), followed by select references to images of the scenes with hedgehog-head boats, particularly those post-dating Droste zu Hülshoff (1980). In the case of partially published or unpublished tombs from Giza, references to their corresponding photographic ID from the Digital Giza project (giza.fas.harvad.edu) have been provided.

References to Droste zu Hülshoff's (1980) catalogue are provided in the first instance (abbreviated 'Der Igel no. [X]'), followed by select references to images of the scenes with hedgehog-head boats, particularly those post-dating Droste zu Hülshoff (1980). In the case of partially published or unpublished tombs from Giza, references to their corresponding photographic ID from the Digital Giza project (giza.fas.harvad.edu) have been provided.

A possible further example is from the tomb of Khunes at Zaweit el-Maiyiten (Varille 1938, p. 15, fig. 5), although in this case the head of the hedgehog is not (yet) modeled. The scene is very similar to that found in Nefer and Kahay at Saqqara (Harpur and Scremin 2010, p. 463, n. 293).

I thank Yvonne Harpur for this observation, which cannot be made out in Altenmüller's (1998, pl. 69) publication of the scene. The Oxford Expedition to Egypt's publication of photographic scene details from the tomb of Mehu is forthcoming. 
The dating of the tomb of Seneb is unresolved, but it probably falls between the end of the 4 th Dynasty and the end of the 5 th Dynasty (overview: Woods 2011).

The examples from El-Hamammiya, Zaweit el-Maiyitin, and Meir (noted in Table 1) can be compared to a contemporaneous scene in the 6th Dynasty tomb of Ibi at Deir el-Gebrawi, with two ships under sail in convoy but without a hedgehog-head boat (Davies 1901, pl. 19).

Comparable marsh fowling scenes that may have once included hedgehog-head boats occur in the 5th Dynasty tombs of Werirni (A 25) at el-Sheikh Said (Davies 1901, pl. 5), and possibly also Niankhpepy (Tomb 14) at Zaweit el-Maiyitin (Varille 1938, pl. 5), but in both of these examples the front part of the boat is destroyed. With thanks to Yvonne Harpur for this observation. On religious practice in petroglyph making, see Huyge (2002).

The scene of ships in convoy from the tomb chapel of Irukaptah at Saqqara, which includes a hedgehog-head boat, can be compared with that of the 6th Dynasty official Remni at Saqqara, for example, even though the latter does not include a hedgehoghead boat (Kanawati 2009, pp. 37-38, pl. 38a, 52). A simpler expression of this motif is found on the fragmentary false-door of Pernedju from Saqqara (now in Private Collection) studied by Galán (2000, pp. 148-50); in the case of Pernedju, the choice to place this scene prominently in association with his false-door may be connected to his professional connection to royal boats as 'Scribe of the Crew' and 'Scribe of the enrolment of the boat's crew', but contra Galán (2000, p. 150) all of these boat-types are associated with vessels found in non-royal contexts and are probably not royal property.

More generally on the status of Old Kingdom officials in the 5th-6th Dynasties and the boats they may have owned, see Kessler $(1987$, p. 67f.).

In an early 17th century CE study of ancient Egyptian language by Kircher (1636, p. 165), the word nI\$YNoc is proposed as the Coptic word for hedgehog (followed by the Latin Erinacius), probably to be understood as the definite article $\Pi(p-)$ followed by a word $\phi Y N O c$, the etymology of which remains obscure. One possibility is a further combination of definite article $\Pi(p-)$ plus úv(v)เS (hún(n)is), the Greek word for 'ploughshare', proposed to be etymologically connected with the word for 'hog' $(\tilde{v} \zeta)$ by Plutarch, because its action resembles the rooting of a hog's snout. It is also possible that Kircher misread ח।фүNOC in a written source for חIXYNOC, חIXINOC, or חIEXINOC, all of which could be hypothetically analysed as Coptic versions of the ancient

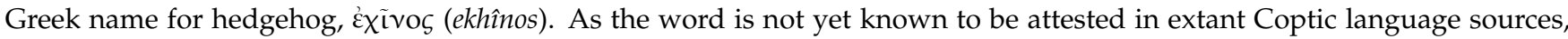
these restorations are speculative. Moreover, Kircher incorrectly paired the word with the Arabic name for a jerboa (يربوع)

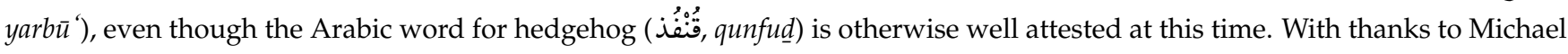
Zellmann-Rohrer for these remarks on the possible etymology of $\Pi 1 \phi Y$ NOC and Kircher's (mis-)translations of Coptic and Arabic. On faunal nomenclature: Vernus and Yoyotte (2005, pp. 76-89). A recent study that considers methodological and epistemological issues of zoological categories in past societies: Brémont et al. (2020). On animals in ancient Egyptian art and language: e.g., Thuault (2019); the collected articles in Porcier et al. (2019); Gerke (2017); Evans (2010a, 2015); McDonald (2014); Arnold (2010), cf. earlier Arnold (1994), Houlihan (2002); Osborn and Osbornová (1998).

It is important to note that the actual transcription is $h-t-n$ (cf. Junker 1941, p. 64), although the displacement of hieroglyphic signs within words, especially in Old Kingdom captions, is not unusual.

The possibility that Mnjw, in this instance, could also be the name of the figure close to the caption (e.g., see Mjn.w [sic] in Scheele-Schweitzer 2014, p. 370 [1203]) cannot be wholly excluded, also noted by Altenmüller (2000, p. 7). However, mnjw is extremely common as a word for 'herdsman' in Old Kingdom tombs in comparable contexts.

A comparable use of this sign occurs on the north wall of the 4th Dynasty tomb of Rahotep at Meidum (Petrie 1892, pl. 14).

Although see also Altenmüller (2007, pp. 19-20), who draws a hypothetical link between hedgehog-head boats and Khnum through references to Khnum as a 'ferryman' in the Pyramid and Coffin Texts; none of these passages make use of the lexeme hnt(j).

38 In addition to the examples collected by Droste zu Hülshoff (1980, pp. 81-92), an exceptional example can be added of a live hedgehog being supported in the palm of an offering bearer in the 6th Dynasty tomb of Kagemni at Saqqara (Harpur and Scremin 2006, p. 241 [379]). This was later re-carved into a covered vessel, but its snout, legs, and curved back are all unmistakable in the relief when closely examined.

I thank Yvonne Harpur for the observation that hedgehogs do not occur among visual or tabulated scenes of offerings in Old Kingdom tombs. On live (and 'fattened') gazelles being brought to the tomb and their appearance in offering lists, see e.g., Strandberg (2009, p. 120f.). Fitzenreiter (2009) cautions against overinterpreting the absense (or perhaps even avoidance) of certain animals represented for consumption in Old Kingdom funerary reliefs. In addition to the numerous scenes that reference ritual butchery, the tethering stone in the 6th Dynasty chapel of Mereruka at Saqqara is possibly architectural evidence of this occurring within the tomb chapel (described in Kanawati et al. 2010, p. 39).

40 See recently, e.g., Thuault (2020), Roth (2017). While falling well outside of the scope of this study, there is an intriguing reference in Aristotle (Historia animalium, 9.6) to some hedgehogs as oi $\delta^{\prime} \varepsilon^{\prime} v \tau \alpha \tilde{I}_{\zeta}$ oíkí $\alpha \iota \zeta \tau \varepsilon \varepsilon \varphi$ ó $\mu \varepsilon v o l$ ('those kept in the houses'), without further elaboration (trans. Mackay 2016, p. 236, n. 39). Kitchell (2017, p. 191) has proposed that hedgehogs may have been used as 'pest control' in ancient houses. 
Albeit, rarely attested and primarily in the New Kingdom; e.g., oDeM 1646 (1. [Frg. 4, x+2]); tomb of Seti I (KV 17), Book of the Heavenly Cow (1. 58).

\section{References}

Adams, Barbara. 1974. Ancient Hierakonpolis. Warminster: Aris and Phillips.

Alexanian, Nicole, and Tomasz Herbich. 2014-2015. The workmen's barracks south of the Red Pyramid at Dahshur. Mitteilungen des Deutschen Archäologischen Instituts, Abteilung Kairo 70-71: 13-23.

Alexanian, Nicole, Robert Schiestl, and Stephan J. Seidlmayer. 2015. The necropolis of Dahshur: Fourth excavation report spring 2007. Annales du Service des Antiquités de l'Égypte 86: 15-26.

Altenmüller, Hartwig. 1976. Das Ölmagazin im Grab des Hesire in Saqqara (QS 2405). Studien zur Altägyptischen Kultur 4: 1-29.

Altenmüller, Hartwig. 1998. Die Wanddarstellungen im Grab des Mehu in Saqqara. Archäologische Veröffentlichungen, Deutsches Archäologisches Institut, Abteilung Kairo 42. Mainz: Philipp von Zabern.

Altenmüller, Hartwig. 2000. Die Nachtfahrt des Grabherrn im Alten Reich: Zur Frage der Schiffe mit Igelkopfbug. Studien zur Altägyptischen Kultur 28: 1-26.

Altenmüller, Hartwig. 2002a. Der Himmelsaufstieg des Grabherrn: Zu den Szenen des zSS wAD in den Gräbern des Alten Reiches. Studien zur Altägyptischen Kultur 30: 1-42.

Altenmüller, Hartwig. 2002b. Funerary boats and boat pits of the Old Kingdom. Archív Orientální 70: 269-90.

Altenmüller, Hartwig. 2005. Licht und Dunkel, Tag und Nacht: Programmatisches aus der Dekoration der Gräber des Alten Reiches. In Texte und Denkmäler des ägyptischen Alten Reiches. Edited by Stephan J. Seidlmayer. Berlin: Achet, Dr. Norbert Dürring, pp. 9-26.

Altenmüller, Hartwig. 2007. Zur Herkunft und Bedeutung der Schiffe mit Igelkopfbug. Bulletin of the Egyptian Museum 4: 13-22.

Andrews, Carol. 1994. Amulets of ancient Egypt. London: The British Museum Press.

Arnold, Dorothea. 1994. An Egyptian bestiary. The Metropolitan Museum of Art Bulletin 52: 7-64. [CrossRef]

Arnold, Dorothea. 2010. Falken, Katzen, Krokodile: Tiere im Alten Ägypten; aus den Sammlungen des Metropolitan Museum of Art, New York, und des Ägyptischen Museums Kairo. Zürich: Museum Rietberg.

Aufrère, Sydney, and Marguerite Erroux-Morfin. 2001. Au sujet du hérisson. Aryballes et preparations magiques à base d'extraits tires de cet animal. In Encyclopédie Religieuse de l'Univers Végétal Croyances Phytoreligieuses de l'Égypte Ancienne. Edited by Sydney Aufrère. Montpellier: Université Paul Valéry, Montpellier 3, vol. 2, pp. 521-33.

Baines, John. 1987. Practical religion and piety. Journal of Egyptian Archaeology 73: 79-98. [CrossRef]

Baines, John. 1991. Society, morality, and religious practice. In Religion in Ancient Egypt: Gods, Myths, and Personal Practice. Edited by John Baines, Leonard H. Lesko and David P. Silverman. Ithaca: Cornell University Press, London: Routledge, pp. 123-200.

Baines, John. 2001. Egyptian letters of the New Kingdom as evidence for religious practice. Journal of Ancient Near Eastern Religions 1: 1-31. [CrossRef]

Baines, John. 2006. Display of magic in Old Kingdom Egypt. In Through a Glass Darkly: Magic, Dreams E Prophecy in Ancient Egypt. Edited by Kasia Szpakowska. Swansea: Classical Press of Wales, pp. 1-32.

Baines, John. 2017. How can we approach Egyptian personal religion of the third millennium? In L'individu Dans la Religion Égyptienne: Actes de la Journée D'études de L'équipe EPHE (EA 4519) "Égypte Ancienne: Archéologie, Langue, Religion", Paris, 27 Juin 2014. Edited by Christiane Zivie-Coche and Yannis Gourdon. Montpellier: Université Paul-Valéry Montpellier 3, pp. 13-36.

Bárta, Miroslav. 2001. Abusir V: The Cemeteries at Abusir South I. Excavations of the Czech Institute of Egyptology. Praha: Set Out.

Bárta, Miroslav, and Aleš Bezděk. 2008. Beetles and the decline of the Old Kingdom: Climate change in ancient Egypt. In Chronology and Archaeology in Ancient Egypt (the Third Millennium B.C.). Edited by Hana Vymazalová and Miroslav Bárta. Prague: Czech Institute of Egyptology, Faculty of Arts, Charles University in Prague, pp. 214-22.

Belova, Galina A., and Tatiana A. Sherkova. 2002. Ancient Egyptian temple at Tell Ibrahim Awad: Excavations and Discoveries in the Nile Delta / Древнеегипетский храм в Телль Ибрагим Аваде: Раскопки и Открытия в Дельте Нила. Moscow: Aletheia.

Berger, Michael A. 1992. Predynastic animal-headed boats from Hierakonpolis and Southern Egypt. In The Followers of Horus: Studies Dedicated to Michael Allen Hoffman. Edited by Renée Friedman and Barbara Adams. Oxford: Oxbow Books, pp. 107-20.

Blackman, Aylward M. 1924. The Rock Tombs of Meir. Part IV: The Tomb-Chapel of Pepi'onkh the Middle Son of Sebekhotpe and Pekhernefert (D, No. 2). Archaeological Survey of Egypt 25. London and Boston: Egypt Exploration Fund.

Borchardt, Ludwig. 1937. Denkmäler des Alten Reiches (außer den Statuen) im Museum von Kairo, Nr. 1295-1808. Teil 1: Text und Tafeln zu Nr. 1295-1541. Catalogue Général des Antiquités Égyptiennes du Musée du Caire. Berlin: Reichsdruckerei.

Brass, Michael. 2018. Early North African cattle domestication and its ecological setting: A reassessment. Journal of World Prehistory 31: 81-115. [CrossRef]

Brémont, Axelle, Yoan Boudes, Simon Thuault, and Meyssa Ben Saad. 2020. Appréhender les catégories zoologiques en anthropologie historique: Enjeux méthodologiques et épistémologiques. Anthropozoologica 55: 73-93.

Brodie, Edmund. 1977. Hedgehogs use toad venom in their own defense. Nature 268: 627-28. [CrossRef]

Brodie, Edmund, Edmund Brodie Jr., and Judith Johnson. 1982. Breeding the African hedgehog in captivity. International Zoo Yearbook 22: 195-97. [CrossRef]

Brodrick, Mary, and Anna A. Morton. 1899. The tomb of Pepi Ankh (Khua), near Sharona. Proceedings of the Society of Biblical Archaeology 21: $26-33$. 
Brovarski, Edward. 2015. Petrie's pelta palettes. In Lotus and Laurel: Studies on Egyptian Language and Religion in Honour of Paul John Frandsen. Edited by Rune Nyord and Kim Ryholt. Copenhagen: Museum Tusculanum Press, pp. 45-54.

Buchholz, Hans-Günter. 1965. Echinos und Hystrix: Igel und Stachelschwein in Frühzeit und Antike. Berliner Jahrbuch für Vor- und Frühgeschichte 5: 66-92.

Budjaj, Aymane, Guillermo Benítez, and Juan Manuel Pleguezuelos. 2021. Ethnozoology among the Berbers: Pre-Islamic practices survive in the Rif (northwestern Africa). Journal of Ethnobiology and Ethnomedicine 17: 1-21. [CrossRef] [PubMed]

Burn, John W. 2021. A River In 'Drought'? Environment and Cultural Ramifications of Old Kingdom Climate Change. BAR International Series 3036; Oxford: BAR Publishing.

Burton, Maurice. 1957. Hedgehog self-anointing. Proceedings of the Zoological Society of London 129: 452-53.

Bussmann, Richard. 2006. Der Kult im frühen Satet-Tempel von Elephantine. In Archöologie und Ritual: Aufder Suche nach der Rituellen Handlung in den Antiken Kulturen Ägyptens und Griechenlands. Edited by Joannis Mylonopoulos and Hubert Roeder. Wien: Phoibos Verlag, pp. 25-36.

Bussmann, Richard. 2011. Local traditions in early Egyptian temples. In Egypt at Its Origins III: Proceedings of the Third International Conference "Origin of the State: Predynastic and Early Dynastic Egypt", London, UK, 27 July-1 August 2008. Edited by Renée F. Friedman and Peter N. Fiske. Leuven: Peeters, pp. 747-62.

Bussmann, Richard. 2013. The social setting of the temple of Satet in the third millennium. In The First Cataract of the Nile-One Region, Diverse Perspectives. Edited by Stephan Seidlmayer, Dietrich Raue and Philipp Speiser. Mainz: Zabern, pp. 21-34.

Bussmann, Richard. 2015. Changing cultural paradigms: From tomb to temple in the 11th Dynasty. In Proceedings of the Tenth International Congress of Egyptologists, Rhodes, Greece, 22-29 May 2008. Edited by Panagiotis Kousoulis and Nikolaos Lazaridis. Leuven: Peeters, pp. 971-85.

Bussmann, Richard. 2017. Personal piety: An archaeological response. In Company of images: Modelling the Imaginary World of Middle Kingdom Egypt (2000-1500 BC), Proceedings of the International Conference of EPOCHS Project, London, UK, 18-20 September 2014. Edited by Gianluca Miniaci, Marilina Betrò and Stephen Quirke. Leuven: Peeters, pp. 71-91.

Bussmann, Richard. 2019. Practice, meaning and intention: Interpreting votive objects from ancient Egypt. In Perspectives on Lived Religion: Practices-Transmission-Landscape. Papers on archaeology of the Leiden Museum of Antiquities 21. Edited by Nico Staring, Huw Twiston Davies and Lara Weiss. Leiden: Sidestone Press, pp. 73-84.

Ciałowicz, Krzysztof M. 2006. From residence to early temple: The case of Tell el-Farkha. In Archaeology of Early Northeastern Africa: In Memory of Lech Krzyżaniak. Edited by Karla Kroeper, Marek Chłodnicki and Michał Kobusiewicz. Poznan: Archaeological Museum, pp. 917-34.

Cooper, Julien, and Dorian Vanhulle. 2019. Boats and routes: New rock art in the Atbai desert. Sudan E Nubia 23 : 3-12.

Creasman, Pearce Paul. 2013. Ship timber and the reuse of wood in ancient Egypt. Journal of Egyptian History 6: 152-76. [CrossRef]

Creasman, Pearce Paul, and Noreen Doyle. 2015. From pit to procession: The diminution of ritual boats and the development of royal burial practices in pharaonic Egypt. Studien zur Altägyptischen Kultur 44: 83-101.

Davies, Norman de Garis. 1901. The rock tombs of Sheikh Saïd. London: Egypt Exploration Fund.

Davies, Norman de Garis. 1953. The temple of Hibis in el Khärgeh Oasis Part III: The decoration. Publications of the Metropolitan Museum of Art Egyptian Expedition 17. Edited by Ludlow S. Bull and Lindsley F. Hall. New York: Metropolitan Museum of Art.

De Dominicis, Danilo. 2019. Unguentari a forma di riccio nel Mediterraneo tra Naukratis e l'Etruria. In Atti del XVII Convegno di Egittologia e Papirologia: Siracusa, 28 Settembre-1 Ottobre 2017. Edited by Anna Di Natale and Corrado Basile. Siracusa: Istituto internazionale del papiro-Museo del papiro "Corrado Basile", pp. 99-110.

Dreyer, Günter. 1986. Elephantine VIII: Der Tempel der Satet. Die Funde der Frühzeit und des Alten Reiches. Archäologische Veröffentlichungen, Deutsches Archäologisches Institut, Abteilung Kairo 39. Mainz: Philipp von Zabern.

Droste zu Hülshoff, Vera von. 1980. Der Igel im Alten Ägypten. Hildesheimer Ägyptologische Beiträge 11. Hildesheim: Gerstenberg.

Dunham, Dows, and William K. Simpson. 1974. The Mastaba of Queen Mersyankh III. G 7530-7540: Based upon the Excavations and Recordings of the Late George Andrew Reisner and William Stevenson Smith. Museum of Fine Arts-Harvard University Expedition. Giza Mastabas 1. Boston: Museum of Fine Arts.

El Awady, Tarek. 2009. Abusir XVI: Sahure. The Pyramid Causeway: History and Decoration Program in the Old Kingdom. Excavations of the Czech Institute of Egyptology. Prague: Czech Institute of Egyptology, Faculty of Arts, Charles University in Prague.

El-Khouli, Ali, and Naguib Kanawati. 1990. The Old Kingdom Tombs of el-Hammamiya. Australian Centre for Egyptology: Reports 2. Sydney: The Australian Centre for Egyptology.

Épron, Lucienne, François Daumas, Henri Wild, and Georges Goyon. 1939. Le Tombeau de Tî: Dessins et Aquarelles. Le Caire: Institut français d'archéologie orientale.

Esposito, Serena. 2018. Riverboats and seagoing ships: Lexicographical analysis of nautical terms from the sources of the Old Kingdom. In Stories of Globalisation: The Red Sea and the Persian Gulf from Late Prehistory to Early Modernity. Edited by Andrea Manzo, Chiara Zazzaro and Diana Joyce De Falco. Leiden: Brill, pp. 30-52.

Evans, Linda. 2010a. Animal Behaviour in Egyptian Art: Representations of the Natural World in Memphite Tomb Scenes. Australian Centre for Egyptology: Studies 9. Oxford: Aris \& Phillips.

Evans, Linda. 2010b. Otter or mongoose? Chewing over evidence in wall scenes. In Egyptian Culture and Society: Studies in Honour of Naguib Kanawati 1. Edited by Alexandra Woods, Ann McFarlane and Susanne Binder. Le Caire: Conseil Suprême des Antiquités, pp. 119-29. 
Evans, Linda. 2011. The shedshed of Wepwawet: An artistic and behavioural interpretation. Journal of Egyptian Archaeology 97: 103-15. [CrossRef]

Evans, Linda. 2015. Invertebrates in ancient Egyptian art: Spiders, ticks, and scorpions. In Apprivoiser le sauvage/Taming the Wild. Edited by Magali Massiera, Bernard Mathieu and Frédéric Rouffet. Montpellier: Université Paul Valéry Montpellier, vol. 3, pp. 145-57. Evans, Linda, and Philip Weinstein. 2019. Ancient Egyptians' atypical relationship with invertebrates. Society E Animals 27: 716-32.

Evans, Linda, and Vazrick Nazari. 2015. Butterflies of ancient Egypt. Journal of the Lepidopterists' Society 69: $242-67$.

Fakhry, Ahmed. 1942. Bahria Oasis. The Egyptian Deserts. Bulâq: Service des Antiquités de l'Égypte.

Fakhry, Ahmed. 1961. The Valley Temple, Part II: The Finds. The monuments of Sneferu at Dahshur 2. Cairo: General Organisation for Government Printing Offices, Antiquities Department of Egypt.

Fernández Pichel, Abraham I. 2017. La representación zoomorfa de las divinidades egipcias: Yuxtaposición y complementariedad. Polis: Revista de Ideas y Formas Políticas de la Antigüedad Clásica 29: 31-54.

Fitzenreiter, Martin. 2009. On the yonder side of bread and beer: The conceptualization of animal based food in funerary chapels of the Old Kingdom. In Desert Animals in the Eastern Sahara: Statues, Economic Significance, and Cultural Reflection in Antiquity. Edited by Heiko Reimer, Frank Förster, Michael Herb and Nadja Pöllath. Cologne: Heinrich-Barth Institute, pp. 309-40.

Forshaw, Roger. 2014. Before Hippocrates. Healing practices in ancient Egypt. In Medicine, Healing and Performance. Edited by Effie Gemi-Iordanou, Stephen Gordon, Robert Matthew, Ellen McInnes and Rhiannon Pettitt. Oxford: Oxbow, pp. 25-41.

Foster, Benjamin. 2002. Animals in Mesopotamian literature. In A History of the Animal World in the Ancient Near East. Edited by Billie Jean Collins. Leiden: Brill, pp. 271-28.

Galán, José M. 2000. Two Old Kingdom officials connected with boats. Journal of Egyptian Archaeology 86: 145-50. [CrossRef]

Gardiner, Alan H. 1923. The Eloquent Peasant. Journal of Egyptian Archaeology 9: 5-25. [CrossRef]

Gardiner, Alan H. 1969. The Admonitions of an Egyptian Sage from a Hieratic Papyrus in Leiden (Pap. Leiden 344 recto). Reprinted with Additions and Corrections. Leipzig: J. C. Hinrichs.

Gerke, Sonja. 2017. All creatures great and small-The ancient Egyptian view of the animal world. In Classification from Antiquity to Modern Times: Sources, Methods, and Theories from an Interdisciplinary Perspective. Edited by Tanja Pommerening and Walter Bisang. Berlin and Boston: De Gruyter, pp. 67-100.

Germond, Philippe. 2014-2015. En marge de trois petites représentations de hérissons au Musée d'art et d'histoire de Genève. Bulletin de la Société d'Égyptologie de Genève 30: 35-46.

Ghalioungui, Paul. 1987. The Ebers papyrus: A New English Translation, Commentaries and Glossaries. Cairo: Academy of Scientific Research and Technology.

Graff, Gwenola. 2009. Les peintures sur vases de Nagada I-Nagada II: Nouvelle approche sémiologique de l'iconographie prédynastique. Egyptian Prehistory Monographs 6. Leuven: Leuven University Press.

Gundacker, Roman. 2019. Ist Hcjw-mw ‘Wasserzauber' ein 'Älteres Kompositum'? Untersuchungen zu einem terminus technicus der ägyptischenlingua magica. Lingua Aegyptia 27: 77-129. [CrossRef]

Handoussa, Tohfa, and Edward Brovarski. 2021. The Abu Bakr Cemetery at Giza. Wilbour Studies in Egyptology and Assyriology 5. Atlanta: Lockwood Press.

Harpur, Yvonne. 1980. zSS wAD scenes of the Old Kingdom. Göttinger Miszellen 38: 53-61.

Harpur, Yvonne. 1987. Decoration in Egyptian Tombs of the Old Kingdom: Studies in Orientation and Scene Content. Photographs by Paolo J. Scremin. Studies in Egyptology. London and New York: Kegan Paul International.

Harpur, Yvonne, and Paolo Scremin. 2006. The Chapel of Kagemni: Scene Details. Egypt in Miniature 1. Reading and Oxford: Oxford Expedition to Egypt.

Harpur, Yvonne, and Paolo Scremin. 2008. The Chapel of Ptahhotep: Scene Details. Egypt in Miniature 2. Reading and Oxford: Oxford Expedition to Egypt.

Harpur, Yvonne, and Paolo Scremin. 2010. The Chapel of Niankhkhnum and Khnumhotep: Scene Details. Egypt in Miniature 3. Reading and Oxford: Oxford Expedition to Egypt.

Harpur, Yvonne, and Paolo Scremin. 2017. The Chapel of Irukaptah Scene Details and the Chapel of Neferherenptah: Scene Details. Egypt in Miniature 6-7. Reading and Oxford: Oxford Expedition to Egypt.

Hayes, William C. 1953. The Scepter of Egypt: A Background for the Study of the Egyptian Antiquities in the Metropolitan Museum of Art, I. From the Earliest Times to the End of the Middle Kingdom. New York: Harper; Metropolitan Museum of Art.

Hoath, Richard. 2009. A Field Guide to the Mammals of Egypt. Cairo and New York: American University in Cairo Press.

Hornung, Erik, and Elisabeth Staehelin. 1976. Skarabäen und Andere Siegelamulette aus Basler Sammlungen. Mainz: Philipp von Zabern.

Houlihan, Patrick F. 2002. Animals in Egyptian art and hieroglyphs. In A History of the Animal World in the Ancient Near East. Edited by Biller Jean Collins. Leiden: Brill, pp. 97-143.

Huyge, Dirk. 2002. Cosmology, ideology, and personal religious practice in ancient Egyptian rock art. In Egypt and Nubia: Gifts of the Desert. Edited by Renée Friedman. London: British Museum Press, pp. 192-206.

Ikram, Salima. 1995. Choice Cuts: Meat Production in Ancient Egypt. Orientalia Lovaniensia Analecta 69. Leuven: Peeters.

Jones, Dilwyn. 1988. A Glossary of Ancient Egyptian Nautical Titles and Terms. Studies in Egyptology. London and New York: Kegan Paul International.

Jones, Dilwyn. 1995. Boats. Egyptian Bookshelf. London: British Museum Press. 
Junker, Hermann. 1931. The Offering Room of Prince Kaninisut [English Edition]. Collections of the Museum of Fine Arts, Vienna 14. Vienna: Kunsthistorisches Museum.

Junker, Hermann. 1934. Gîza II: Bericht über die von der Akademie der Wissenschaften in Wien auf gemeinsame Kosten mit Dr. Wilhelm Pelizaeus Unternommenen Grabungen auf dem Friedhof des Alten Reiches bei den Pyramiden von Gîza. Die Maștabas der Beginnenden V. Dynastie auf dem Westfriedhof. Akademie der Wissenschaften in Wien, Philosophisch-Historische Klasse 70 (3). Wien: Hölder-Pichler-Tempsky.

Junker, Hermann. 1940. Gîza IV: Bericht über die von der Akademie der Wissenschaften in Wien auf Gemeinsame Kosten Mit Dr. Wilhelm Pelizaeus Unternommen Grabungen auf dem Friedhof des Alten Reichs bei den Pyramiden von Gîza. Die Mastaba des KAjmanx (Kai-emanch). Österreichische Akademie der Wissenschaften, Denkschriften der Philosophisch-Historischen Klasse 71 (1). Wien and Leipzig: Hölder-Pichler-Tempsky.

Junker, Hermann. 1941. Gîza V: Bericht über die von der Akademie der Wissenschaften in Wien auf Gemeinsame Kosten mit Dr. Wilhelm Pelizaeus Unternommen Grabungen auf dem Friedhof des Alten Reichs bei den Pyramiden von Gîza. Die Maștabas des Cnb (Seneb) und die Umliegenden Gräber. Österreichische Akademie der Wissenschaften, Denkschriften der Philosophisch-Historischen Klasse 71 (2). Wien: Hölder-Pichler-Tempsky.

Junker, Hermann. 1943. Gîza VI: Bericht über die von der Akademie der Wissenschaften in Wien auf Gemeinsame Kosten mit Dr. Wilhelm Pelizaeus Unternommen Grabungen auf dem Friedhof des Alten Reichs bei den Pyramiden von Gîza. Die Mastaba des Nfr (Nefer), Kdfji (Kedfi), K3hjf (Kahjef) und die westlich Anschließenden Grabanlagen. Österreichische Akademie der Wissenschaften, Denkschriften der Philosophisch-Historischen Klasse 72 (1). Wien: Hölder-Pichler-Tempsky.

Kanawati, Naguib. 2001. Tombs at Giza. Volume I: Kaiemankh (G4561) and Seshemnefer I (G4940). Australian Centre for Egyptology: Reports 16. Warminster: Aris \& Phillips.

Kanawati, Naguib. 2002. Tombs at Giza. Volume II: Seshathetep/Heti (G5150), Nesutnefer (G4970) and Seshemnefer II (G5080). Australian Centre for Egyptology: Reports 18. Warminster: Aris \& Phillips.

Kanawati, Naguib. 2009. The Teti Cemetery at Saqqara. Volume IX: The tomb of Remni. Australian Centre for Egyptology: Reports 28. Warminster: Aris and Phillips.

Kanawati, Naguib. 2012. The Cemetery of Meir. Volume I: The Tomb of Pepyankh the Middle. Australian Centre for Egyptology: Reports 31. Oxford: Aris \& Phillips.

Kanawati, Naguib, Alexandra Woods, Sameh Shafik, and Effy Alexakis. 2010. Mereruka and His Family, Part III.1-2: The Tomb of Mereruka. Australian Centre for Egyptology: Reports 29-30. Oxford: Aris and Phillips.

Kanawati, Naguib, and Linda Evans. 2014. Beni Hassan. Volume I: The Tomb of Khnumhotep II. Australian Centre for Egyptology: Reports 36. Oxford: Aris and Phillips.

Kanawati, Naguib, and Mahmoud Abdel-Raziq. 2003. The Unis Cemetery at Saqqara. Volume II: The Tombs of Iynefert and Ihy (Reused by Idut). Australian Centre for Egyptology: Reports 19. Warminster: Aris \& Phillips.

Kawai, Nozomu. 2011. An early cult centre at Abusir-Saqqara? Recent discoveries at a rocky outcrop in north-west Saqqara. In Egypt at Its Origins III: Proceedings of the Third International Conference "Origin of the State: Predynastic and Early Dynastic Egypt", London, UK, 27 July-1 August 2008. Edited by Renée F. Friedman and Peter N. Fiske. Leuven: Peeters, pp. 801-28.

Kees, Hermann. 1921. Studien zur Aegyptischen Provinzialkunst. Leipzig: Hinrichs.

Kemp, Barry J. 2006. Ancient Egypt: Anatomy of a Civilization, 2nd Revised ed. London: Routledge.

Kessler, Dieter. 1987. Zur Bedeutung der Szenen des täglichen Lebens in den Privatgräbern (1): Die Szenen des Schiffsbaues und der Schiffahrt. Zeitschrift für ägyptische Sprache und Altertumskunde 114: 59-88. [CrossRef]

Kircher, Athanasius. 1636. Lingua Aegyptiaca Restituta. Rome: L. Grignani for sumptibus Hermanni Scheus.

Kitchell, Kenneth F. 2017. 'Animal Literacy' and the Greeks: Philoctetes the Hedgehog and Dolon the Weasel. In Interactions between Animals and Humans in Graeco-Roman Antiquity. Edited by Thorsten Fögen and Edmund Thomas. Berlin and Boston: De Gruyter, pp. 183-204.

Kopp, Peter. 2013. Votive aus dem Schutt: Der Satet-Tempel auf Elephantine und die Stadterweiterung der 6. Dynastie. In Sanktuar und Ritual: Heilige Plätze im Archäologischen Befund. Edited by Iris Gerlach and Dietrich Raue. Rahden: VML, Marie Leidorf, pp. 307-20.

Kopp, Peter. 2018. Elephantine XXIV: Funde und Befunde aus der Umgebung des Satettempels. Grabungen 2006-2009. Archäologische Veröffentlichungen, Deutsches Archäologisches Institut, Abteilung Kairo 104. Wiesbaden: Harrassowitz.

Kopp, Peter. 2020. Elephantine IX: Der Tempel der Satet. Die Funde des Späten Alten bis Neuen Reichs. Archäologische Veröffentlichungen, Deutsches Archäologisches Institut, Abteilung Kairo 41. Wiesbaden: Harrassowitz.

Kremler, Joylene. 2016. The persistence of style: Frog votive figures from Elephantine. Mitteilungen des Deutschen Archäologischen Instituts, Abteilung Kairo 72: 127-34.

Lacovara, Peter. 2015. The Menkaure valley temple settlement revisited. Bulletin of the Egyptological Seminar 19: 447-54.

Landström, Björn. 1970. Ships of the Pharaohs: 4000 Years of Egyptian Shipbuilding. Architectura Navalis. London: Allen \& Unwin.

Lankester, Francis D. 2013. Desert Boats: Predynastic and Pharaonic era Rock-Art in Egypt's Central Eastern Desert. Distribution, Dating and Interpretation. BAR International Series 2544; Oxford: Archaeopress.

Lankester, Francis D. 2016. Predynastic Egyptian rock art as evidence for early elites' rite of passage. Afrique: Archéologie E Arts 12: 81-92.

Lashien, Miral. 2009. The so-called pilgrimage in the Old Kingdom: Its destination and significance. The Bulletin of the Australian Centre for Egyptology 20: 87-106. 
Latchininsky, Alexandre, Gregory Sword, Michael Sergeev, Maria Marta Cigliano, and Michel Lecoq. 2011. Locusts and grasshoppers: Behavior, ecology, and biogeography. Psyche: A Journal of Entomology 2011: 578327. [CrossRef]

Lehner, Mark, and Zahi Hawass. 2017. Giza and the Pyramids: The Definitive History. London: Thames \& Hudson.

Leonard, Albert. 2000. Why a Hedgehog? In The Archaeology of Jordan and Beyond. Edited by Lawrence E. Stager, Joseph A. Greene and Michael D. Coogan. Leiden: Brill, pp. 310-16.

Lippert, Sandra L. 2012. Stachelschwein, Igel und Schmetterlingspuppe. In 'Parcourir L'éternitê': Hommages à Jean Yoyotte 2. Edited by Christiane Zivie-Coche and Ivan Guermeur. Turnhout: Brepols, pp. 777-99.

Luiselli, Maria M. 2012. Die 'persönliche Frömmigkeit' in der Ägyptologie: Definition(en), Themen, Terminologie, Forschungsansätze, Ausblicke. In Persönliche Frömmigkeit: Funktion und Bedeutung Individueller Gotteskontakte im Interdisziplinären Dialog; Akten der Tagung am Archäologischen Institut der Universität Hamburg (25-27 November 2010). Edited by Wiebke Friese, Anika Greve, Kathrin Kleibl and Kristina Lahn. Münster: Lit, pp. 37-50.

Mackay, E. Anne. 2016. The baneful hedgehog of ancient Greece. In Rich and Great: Studies in Honour of Anthony J. Spalinger on the Occasion of his 70th Feast of Thoth. Edited by Renata Landgráfová and Jana Mynářová. Prague: Charles University, Faculty of Arts, pp. 233-37.

Mark, Samuel. 2013. Graphical reconstruction and comparison of royal boat iconography from the causeway of the Egyptian king Sahure (c. 2487-2475 BC). International Journal of Nautical Archaeology 42: 270-85. [CrossRef]

Maydana, Sebastián F. 2021. Bringing the desert to the Nile: Some thoughts on a predynastic terracotta model. Archéo-Nil 31: 61-80.

McDonald, Angela. 2014. Animals in Egypt. In Oxford Handbooks Online. Edited by Gordon Lindsay Campbell. Glasgow: University of Glasgow. [CrossRef]

McFarlane, Ann. 2000. The Unis Cemetery at Saqqara. Volume I: The Tomb of Irukaptah. Australian Centre for Egyptology: Reports 15. Warminster: Aris \& Phillips.

McNamara, Liam. 2008. The revetted mound at Hierakonpolis and early kingship: A re-interpretation. In Egypt at Its Origins II: Proceedings of the International Conference "Origin of the State. Predynastic and Early Dynastic Egypt", Toulouse, France, 5-8 September 2005. Edited by Béatrix Midant-Reynes and Yann Tristant. Leuven: Peeters, pp. 901-36.

Meyer, Gudrun. 1990. Das Hirtenlied in den Privatgräbern des Alten Reiches. Studien zur Altägyptischen Kultur 17: $235-84$.

Mogensen, Maria. 1921. Le mastaba égyptien de la Glyptothèque Ny Carlsberg. Copenhague: Gyldendalske Boghandel-Nordisk Forlag.

Morales, Antonio J. 2006. Traces of official and popular veneration to Nyuserra Iny at Abusir: Late Fifth Dynasty to Middle Kingdom. In Abusir and Saqqara in the Year 2005: Proceedings of the Conference Held in PRAGUE (June 27 July 5, 2005). Edited by Miroslav Bárta, Filip Coppens and Jaromír Krejčí. Prag: Czech Institute of Egyptology, Faculty of Arts, Charles University in Prague, pp. 311-41.

Mostafa, Maha M. F. 1982. Untersuchungen zu Opfertafeln im Alten Reich. Hildesheimer Ägyptologische Beiträge 17. Hildesheim: Gerstenberg.

Moussa, Ahmed M., and Hartwig Altenmüller. 1977. Das Grab des Nianchchnum und Chnumhotep. Archäologische Veröffentlichungen, Deutsches Archäologisches Institut, Abteilung Kairo 21. Mainz: Zabern.

Ogdon, Jorge R. 1987. Studies in ancient Egyptian magical thought III: Knots and ties. Notes on ancient ligatures. Discussions in Egyptology 7: 29-36.

Ogdon, Jorge R. 1989. Studies in ancient Egyptian magical thought IV: An analysis of the 'technical' language in the anti-snake magical spells of the Pyramid Texts (PT). Discussions in Egyptology 13: 59-71.

Osborn, Dale J., and Helmy Ibrahim. 1980. The Contemporary Land Mammals of Egypt (Including Sinai). Chicago: Field Museum of Natural History.

Osborn, Dale J., and Jana Osbornová. 1998. The Mammals of Ancient Egypt. The Natural History of Egypt 4. Warminster: Aris \& Phillips.

Parkinson, Richard B. 2002. Poetry and Culture in Middle Kingdom Egypt: A Dark Side to Perfection. Athlone Publications in Egyptology and Ancient Near Eastern Studies. London and New York: Continuum.

Parkinson, Richard B. 2012. The Tale of the Eloquent Peasant: A Reader's Commentary. Lingua Aegyptia, Studia Monographica 10. Hamburg: Widmaier.

Petrie, W. M. Flinders. 1892. Medum. London: Nutt.

Petrie, W. M. Flinders. 1901. Diospolis Parva: The Cemeteries of Abadiyeh and Hu 1898-99. London: Egypt Exploration Fund.

Petrie, W. M. Flinders, Edward R. Ayrton, Charles T. Currelly, and Arthur E. Weigall. 1902-1904. Abydos. Memoir of the Egypt Exploration Fund 22; 24; 25. London: Egypt Exploration Fund.

Pinch, Geraldine. 1993. Votive Offerings to Hathor. Oxford: Griffith Institute; Ashmolean Museum.

Pinch, Geraldine, and Elizabeth A. Waraksa. 2009. Votive practices. In UCLA Encyclopedia of Egyptology. Edited by Jacco Dieleman and Willeke Wendrich. Available online: http:/ / digital2.library.ucla.edu/viewItem.do?ark=21198/zz001nfbgg (accessed on 20 November 2021).

Popko, Lutz, Ulrich Johannes Schneider, and Reinhold Scholl. 2021. Papyrus Ebers: Die größte Schriftrolle zur Altägyptischen Heilkunst. Darmstadt: Wbg Edition.

Porcier, Stéphanie, Salima Ikram, and Stéphane Pasquali. 2019. Creatures of Earth, Water, and Sky: Essays on Animals in Ancient Egypt and Nubia. Leiden: Sidestone.

Priese, Karl-Heinz. 1984. Die Opferkammer des Merib. Berlin: Ägyptisches Museum.

Quack, Joachim F. 2002. Some Old Kingdom execration figurines from the Teti Cemetery. The Bulletin of the Australian Centre for Egyptology 13: 149-60. 
Quibell, James E., and Frederick W. Green. 1900-1902. Hierakonpolis. British School of Archaeology in Egypt and Egyptian Research Account 4-5. London: Bernard Quaritch.

Quirke, Stephen. 2015. Exploring Religion in Ancient Egypt. Blackwell Ancient Religions. Chichester and Malden: Wiley Blackwell.

Reeve, Nicholas. 1994. Hedgehogs. London: Poyser.

Roth, Ann Macy. 2011. Objects, animals, humans, and hybrids: The evolution of early Egyptian representations of the divine. In Dawn of Egyptian Art. Edited by Diana Craig Patch. New York and London: Metropolitan Museum of Art, pp. 194-201.

Roth, Ann Macy. 2017. Fear of hieroglyphs: Patterns of suppression and mutilation in Old Kingdom burial chambers. In Essays for the Library of Seshat: Studies Presented to Janet H. Johnson on the Occasion of her 70th Birthday. Edited by Robert Ritner. Chicago: The Oriental Institute of the University of Chicago, pp. 291-310.

Rushdy, Mahmud. 1911. Some notes on the hedgehog. Annales du Service des Antiquités de l'Égypte 11: 181-82.

Scheele-Schweitzer, Katrin. 2014. Die Personennamen des Alten Reiches: Altägyptische Onomastik Unter lexikographischen und SozioKulturellen Aspekten. Philippika 28. Wiesbaden: Harrassowitz.

Schürmann, Wolfgang. 1983. Die Reliefs aus dem Grab des Pyramidenvorstehers Ii-Nefret. Karlsruhe: C. F. Müller.

Seidlmayer, Stephan J. 1997. Stil und Statistik: Die Datierung dekorierter Gräber des Alten Reiches—ein Problem der Methode. In Archäologie und Korrespondenzanalyse: Beispiele, Fragen, Perspektiven. Edited by Johannes Müller and Andreas Zimmermann. Espelkamp: Marie Leidorf, pp. 17-51.

Shaikh Al Arab, Walid. 2019. The hedgehog goddess Abaset. Papyrologica Lupiensia 28: 81-102.

Sherbiny, Hend, and Hussein Bassir. 2014. The representation of the hedgehog goddess Abaset at Bahariya Oasis. Journal of the American Research Center in Egypt 50: 171-89. [CrossRef]

Shoaib, Waheid M. 2014. Unpublished chapel of Ty in the Egyptian Museum (CG 1380, 1696, 1699, 1700-01). Journal of the American Research Center in Egypt 50: 1-29. [CrossRef]

Snedegar, Keith. 2008. Astronomy in Sub-Saharan Africa. In Encyclopaedia of the History of Science, Technology, and Medicine in Non-Western Cultures. Edited by Helain Selin. Berlin and Heidelberg: Springer. [CrossRef]

Spieser, Cathy. 2001. Serket, protectrice des enfants à naître et des défunts à renaître. Revue d'Égyptologie 52: 251-64. [CrossRef]

Steindorff, George. 1946. Catalogue of the Egyptian Sculpture in the Walters Art Gallery. Baltimore: Walters Art Gallery.

Stephens, Michael Allen. 2012. A Categorisation and Examination of Egyptian Ships and Boats from the Rise of the Old to the End of the Middle Kingdoms. BAR International Series 2358; Oxford: Archaeopress.

Strandberg, Åsa. 2009. The Gazelle in Ancient Egyptian Art: Image and Meaning. Uppsala Studies in Egyptology 6. Uppsala: Uppsala University.

Tallet, Pierre. 2012. La Zone Minière Pharaonique du Sud-Sinaï-I: Catalogue Complémentaire des Inscriptions du Sinaï. Mémoires publiés par les membres de l'Institut français d'archéologie orientale 130. Le Caire: Institut français d'archéologie orientale.

Tavares, Ana. 2014. Prickly protection: Sailing in a hedgehog boat. AERAgram 15: 36.

Tavares, Ana, Daniel Jones, Freya Sadarangani, and Hanan Mahmoud. 2014. Excavations east of the Khentkawes Town in Giza: A preliminary site report. Bulletin de l'Institut Français d'Archéologie Orientale 114: 519-61.

Thuault, Simon. 2019. Animal categorisation during the Old Kingdom: Lexicography, hieroglyphs and iconography. In Old Kingdom Art and Archaeology 7: Proceedings of the International Conference; Università degli studi di Milano, Milan, Italy, 3-7 July 2017. Edited by Patrizia Piacentini and Alessio Delli Castelli. Milano: Pontremoli, pp. 322-31.

Thuault, Simon. 2020. L'iconicité des hiéroglyphes égyptiens: La question de la mutilation. Zeitschrift für ägyptische Sprache und Altertumskunde 147: 106-14. [CrossRef]

Tjusi, Asuka. 2016. The depiction of Muslims in the miracles of Anba Barsauma al-Uryan. In Studies in Coptic Culture: Transmission and Interaction. Edited by Mariam Ayad. Oxford: American University in Cairo Press, pp. 65-77.

Tooley, Angela M. 1995. Egyptian Models and Scenes. Shire Egyptology 22. Princes Risborough: Shire Publications.

van Haarlem, Willem. 1996. A remarkable 'hedgehog-ship' from Tell Ibrahim Awad. Journal of Egyptian Archaeology 82: 197-98. [CrossRef]

van Haarlem, Willem. 1998a. Archaic shrine models from Tell Ibrahim Awad. Mitteilungen des Deutschen Archäologischen Instituts, Abteilung Kairo 54: 183-85.

van Haarlem, Willem. 1998b. The excavations at Tell Ibrahim Awad (Eastern Nile Delta): Recent results. In Proceedings of the Seventh International Congress of Egyptologists, Cambridge, UK, 3-9 September 1995. Edited by Chris Eyre. Leuven: Peeters, pp. 509-13.

van Haarlem, Willem. 2019. Temple Deposits in Early Dynastic Egypt: The Case of Tell Ibrahim Awad. BAR International Series 2931; Oxford: BAR Publishing.

van Walsem, René. 2005. Iconography of Old Kingdom Elite Tombs: Analysis and Interpretation, Theoretical and Methodological Aspects. Mededelingen en Verhandelingen van het Vooraziatisch-Egyptisch Genootschap "Ex Oriente Lux" 35. Dudley: Peeters.

van Walsem, René. 2006. Sense and sensibility: On the analysis and interpretation of the iconography programmes in four Old Kingdom elite tombs. In Dekorierte Grabanlagen im Alten Reich: Methodik und Interpretation. Edited by Martin Fitzenreiter and Michael Herb. London: Golden House Publications, pp. 277-332.

Vandier, Jacques. 1957. Le groupe et la table d'offrandes d'Ankhoudjès. Revue D'égyptologie 11: 145-55.

Vandier, Jacques. 1964. Manuel D'archéologie Égyptienne, Tome IV: Bas-Reliefs et Peintures—Scènes de la vie Quotidienne. Paris: Éditions A. et J. Picard et Cie. 
Vanhulle, Dorian. 2018a. Preliminary observations on some Naqadian boat models: A glimpse of a discrete ideological process in pre-pharaonic arts. In Desert and the Nile: Prehistory of the Nile Basin and the Sahara. Papers in Honour of Fred Wendorf. Edited by Jacek Kabaciński, Marek Chłodnicki, Michał Kobusiewicz and Małgorzata Winiarska-Kabacińska. Poznań: Poznań Archaeological Museum, pp. 289-312.

Vanhulle, Dorian. 2018b. Boat symbolism in predynastic and early dynastic Egypt: An ethno-archaeological approach. Journal of Ancient Egyptian Interconnections 17: 173-87.

Varille, Alexandre. 1938. La Tombe de Ni-Ankh-Pepi à Zâouyet el-Mayetîn. Mémoires publiés par les membres de l'Institut français d'archéologie orientale 70. Le Caire: Institut français d'archéologie orientale.

Vassilika, Eleni. 1995. Egyptian Art. Fitzwilliam Museum Handbooks. Cambridge: Cambridge University Press.

Verner, Miroslav. 1992. Funerary boats of Neferirkare and Raneferef. In The Intellectual Heritage of Egypt: Studies Presented to László Kákosy by Friends and Colleagues on the Occasion of His 60th Birthday. Edited by Ulrich Luft. Budapest: Chaire d'Égyptologie, pp. 587-602.

Vernus, Pascal, and Jean Yoyotte. 2005. Bestiaire des Pharaons. Paris: Agnès Viénot; Perrin.

Vinson, Steve. 1994. Egyptian Boats and Ships. Shire Egyptology 20. Princes Risborough: Shire Publications.

Vittmann, Günther. 2013. Personal names: Function and significance. In UCLA Encyclopedia of Egyptology. Edited by Elizabeth Frood, Jacco Dieleman and Willeke Wendrich. Available online: http:/ / digital2.library.ucla.edu/viewItem.do?ark=21198/zz002dwqr7 (accessed on 20 November 2021).

Webb, Virginia. 1978. Archaic Greek faience: Miniature Scent Bottles and Related Objects from East Greece, 650-500 B.C. Warminster: Aris and Phillips.

Wegner, Josef. 2017. A royal boat burial and watercraft tableau of Egypt's 12th Dynasty (c.1850 BCE) at South Abydos. International Journal of Nautical Archaeology 46: 5-30. [CrossRef]

Weiss, Lara. 2012. Individuum und Gemeinschaft: Methodologische Überlegungen zur Persönlichen Frömmigkeit. In Sozialisationen: Individuum-Gruppe—Gesellschaft: Beiträge des Ersten Münchner Arbeitskreises Junge Aegyptologie (MAJA 1), 3. bis 5.12.2010. Edited by Gregor Neunert, Kathrin Gabler and Alexandra Verbovsek. Wiesbaden: Harrassowitz, pp. 187-205.

Wendorf, Fred, and Romuald Schild. 2001. Conclusions. In Holocene Settlement of the Egyptian Sahara, Volume 1: The Archaeology of Nabta Playa. Edited by Fred Wendorf and Romuald Schild. New York: Kluwer Academic/Plenum, pp. 648-75.

Wengrow, David. 2006. The Archaeology of Early Egypt: Social Transformations in North-East Africa, 10,000 to 2650 BC. Cambridge World Archaeology. Cambridge: Cambridge University Press.

Wildung, Dietrich. 2011. Tierbilder und Tierzeichen im Alten Ägypten. Berlin and München: Deutscher Kunstverlag.

Wilkinson, Toby. 1999. Early Dynastic Egypt. London and New York: Routledge.

Woods, Alexandra. 2011. zšš w3 d scenes of the Old Kingdom revisited. In Old Kingdom, New Perspectives: Egyptian Art and Archaeology 2750-2150 BC. Edited by Nigel Strudwick and Helen Strudwick. Oxford: Oxbow Books, pp. 314-19.

Woods, Alexandra. 2015. Five significant features in Old Kingdom spear-fishing and fowling scenes. In Proceedings of the Tenth International Congress of Egyptologists. Edited by Panagiotis Kousoulis and Nikolaos Lazaridis. Leuven: Peeters, pp. $1897-910$.

Yoshimura, Sakuji, Nozomu Kawai, and Hiroyuki Kashiwagi. 2005. A sacred hillside at northwest Saqqara: A preliminary report on the excavations 2001-2003. Mitteilungen des Deutschen Archäologischen Instituts, Abteilung Kairo 61: 361-402.

Yoyotte, Jean. 1960. Les pèlerinages dans l'Égypte ancienne. In Les Pèlerinages: Égypte Ancienne, Israël, Islam, Perse, Inde, Tibet, Indonésie, Madagascar, Chine, Japon. Anonymous Editor. Paris: Éditions du Seuil, pp. 17-74.

Ziegler, Christiane. 1993. Le Mastaba D'akhethetep: Une Chapelle Funéraire de l'Ancien Empire. Paris: Editions de la Réunion des Musées Nationaux.

Zorn, Olivia. 2009. Die Opferkammer des Merib. Sokar 19: 38-45.

Zorn, Olivia, and Dana Bisping-Isermann. 2011. Die Opferkammern im Neuen Museum Berlin. Berlin: Michael Haase. 